This article has been published in a revised form inBusiness Ethics Quarterly [http://doi.org/10.1017/beq.2016.54]. This version is free to view and download for private research and study only. Not for re-distribution or re-use. @ Cambridge University Press 2017.

\title{
CORPORATE PHILANTHROPY \& RISK MANAGEMENT: AN INVESTIGATION OF REINSURANCE \& CHARITABLE GIVING IN INSURANCE FIRMS
}

\author{
Mike Adams* \\ School of Management, \\ University of Bath, \\ Claverton Down, \\ Bath, BA2 7AY, \\ UK \\ Stefan Hoejmose, \\ School of Management, \\ University of Bath, \\ Claverton Down, \\ Bath, BA2 7AY, \\ UK \\ Zafeira Kastrinaki \\ School of Management, \\ University of Bath, \\ Claverton Down, \\ Bath, BA2 7AY, \\ UK
}

Version: July, 2016

\section{Acknowledgements}

We appreciate the assistance of Liudmila Chambers, Elena Veprauskaite, Jerry Goodstein (Associate Editor), and two anonymous reviewers. The paper also benefited from the comments and suggestions of participants at the International Association for Business and Society (IABS) Conference, 2014, Sydney, Australia. However, the normal disclaimer applies. 


\section{CORPORATE PHILANTHROPY \& RISK MANAGEMENT: AN INVESTIGATION OF REINSURANCE \& CHARITABLE GIVING IN INSURANCE FIRMS}

\section{INTRODUCTION}

In this study we examine the empirical relation between corporate charitable donations - a significant item of discretionary strategic spending (McKinsey, 2015), and reinsurance (i.e., 'insurance for insurers') in the United Kingdom's (UK) non-life (propertycasualty) insurance industry. In doing so, we build on a growing body of research that focuses on the strategic insurance role of corporate social responsibility (CSR) activities (e.g., Godfrey, 2005; Godfrey, Merrill \& Hansen, 2009; Godfrey, Hatch \& Hansen, 2010). More recent research in this field (e.g., den Hond, Rehbein, Bakker \& Lankveld, 2014; Jia, 2014; Marquis \& Qian, 2014) points to potential substitution effects and complementarities between CSR and the risk management benefits of corporate political activities. Such 'CSRas-insurance' studies are predicated, at least implicitly, on the strategic stakeholder notion that a firm's long-term financial success is dependent on the confidence that stakeholders have in the integrity and ethicality of its business practices. Further, research suggests that CSR investment builds insurance protection in the form of positive 'moral capital' and protects firm value following a major negative event (e.g., a major governance failure) by appeasing key constituent interests (Jo \& Na, 2012). Chiu \& Sharfman (2011) add that 'CSRas-insurance' increases a firm's legitimacy with stakeholders and enables it to realize sustainable competitive advantages over market rivals. However, prior studies have not examined empirically the strategic tensions that can arise between CSR-type activities (such as charitable giving) and other discretionary (especially financial-type) risk management activities in firms. In our view, this is an important omission given that firms across all industries habitually engage to a greater or lesser extent in both CSR-type investments and the use of risk transfer mechanisms such as commercial insurance.

The present study contributes to the management literature by examining the substitutive/complementary relation between charitable giving and reinsurance - a risk hedging mechanism that is routinely purchased by insurers in order to protect the contractual and transactional interests of stakeholders (e.g., investors, policyholders, and regulators) against bankruptcy and other financial risks (Abdul Kader, Adams \& Mouritidis, 2010). In setting ourselves this goal, we also directly respond to Koh, Qian \& Wang's (2014) recent 
call for scholars to investigate the connectivity between corporate social performance (CSP) and other risk mitigation mechanisms used by firms. The notion that the practice of corporate risk management involves managers selecting from a 'menu' of hedging options is wellrecognized in the finance literature (e.g., Rochet \& Villeneuve, 2011). However, theoretical and empirical research on the inter-relation between different risk mitigation strategies, including CSR activities, is still relatively undeveloped. The present study thus seeks to address this gap in the literature and advance understanding of the linkages between 'CSR-asinsurance' and conventional risk management techniques such as the corporate purchase of (re)insurance. Our study also sheds light on why certain firms are more philanthropic than others - an empirical issue of interest to multiple stakeholders, including market investors, customers, industry regulators, and the general public.

The remainder of our paper is structured as follows. In the next section, we give background information on the UK's non-life insurance industry, and introduce the strategic stakeholder functions of reinsurance and philanthropy. The third section puts forward our two main alternate paired-hypotheses, and explains the moderating-effects of board composition. The fourth section outlines the research design, including the description of the data, model specifications, firm-specific controls, and the variables used. The fifth section then presents the empirical results, and the final part of the paper discusses and concludes the study.

\section{RESEARCH CONTEXT AND THEORETICAL FRAMEWORK}

\section{CSR and the Insurance Industry}

The international insurance industry has long had a strategic interest in the CSR (e.g., environmental protection) activities of its corporate clients (e.g., oil and gas companies) as part of its routine underwriting procedures (Hsu, 2012). However, over the last decade or so CSR in the insurance industry has acquired a much higher profile in the public media than hitherto had been the case (WestLB AG, 2004; McKinsey, 2015). The increased visibility of CSR activities highlights the important role that insurers play in economy and society as both bearers/traders of insurable risks and institutional investors (Bhambri \& Sonnenfeld, 1988). The increased public salience of CSR also reflects the greater political scrutiny of financial services firms following the 2007/8 global financial crisis and the major government bailouts of failed financial firms, most notably the US\$182 billion US federal government support for the American International Group (AIG) (Walls, Berrone \& Phan, 2012). Recently, scholars such as Aguinis \& Glavas (2012), Marquis \& Qian (2014), and den Hond et al. (2014) posit that firms operating in high profile and heavily regulated sectors, such as financial services, 
could voluntarily engage in philanthropy in order to secure economic and/or political benefits from government agencies (e.g., in terms of tax relief) and/or even avoid the costs of more substantive CSR engagement.

A prominent philanthropic public profile could be strategically important for insurers as their basic business model involves writing a contractual (promissory) commitment to indemnify policyholder-customers for future losses in exchange for the receipt of regular premiums (i.e., 'solidity') (Gaa \& Krinsky, 1988). The contractual nature of insurance transactions not only highlights the ethical (moral) importance of maintaining the trust and confidence of existing as well as prospective policyholders and investors, but also satisfying other key stakeholders such as brokers, reinsurers, and industry regulators, particularly with regard to the maintenance of future solvency (Boubakri, Dionne \& Triki, 2008). The financial and risk management profile of insurers as well as the reputational interests of their managers and industry regulators, can thus be protected through the purchase of reinsurance in a similar way as investing in CSR activities such as charitable giving. Koh et al. (2014) find that CSR engagement is particularly value-enhancing in an ex-ante and ex-post sense for firms (e.g., those in extractive industries) that are intrinsically exposed to potentially high levels of litigation risk and commercial uncertainty. However, in the insurance industry other risk hedging tools, such as reinsurance (and likewise insurance in general industrial firms), could provide more cost-effective 'insurance protection' of a firm's franchise value than contributing to charitable causes. Therefore, in the insurance industry the CSR-risk management relation could be positively or inversely related, or even for some (e.g., small) insurance firms strategically disconnected. These aspects thus make the UK's non-life insurance industry not only a prospectively interesting sector within which to examine the risk management attributes and trade-offs associated with CSR-type activities such as philanthropy but also to extrapolate to the risk management-CSR functions in other industrial sectors, particularly other risk-trading financial firms, such as banks, that relative to their net annual earnings also donate little to charitable causes (Zimmeck \& Pharoah, 2015).

\section{The UK's Non-Life Insurance Industry}

The UK's non-life insurance industry is the third largest in the world (after the US and Japan) and comprises approximately 300 or so active domestically-owned and foreignowned companies, subsidiaries and branches of varying size, ownership structure and output mix, which currently generates approximately $£ 50$ billion (US\$72 billion) in gross annual premiums (International Underwriting Association, 2013) ${ }^{1}$. In addition, 94 active syndicates at the Lloyd's of London insurance market currently underwrite direct non-life premiums of 
roughly $£ 25.3$ billion (US\$37 billion) per annum, mainly in property and casualty lines of insurance (Lloyd's of London, 2014). As made clear earlier, issues of CSP have become even more publicly prominent since the 2007/8 global financial crisis and the associated major corporate failures and government bailouts. Such strategic risk management considerations are also important for UK-based insurers going forward with the implementation of the European Union's (EU) new risk capital (Solvency II) requirements in January 2016. Additionally, trade surveys of CSR in international insurance markets (e.g., WestLB AG, 2004; McKinsey, 2015) indicate that the CSR activities of insurers are potentially of interest to reinsurance companies as well as other stakeholders (e.g., industry regulators). For example, reinsurers could view corporate philanthropy as a signal that their insurance company clients are managed by boards of directors eager to promote a sustainable and socially aware and responsible business model to lawmakers, industry regulators, and others. In turn, such 'public image-building' could help reinsurers to generate future cash flows, increase firm value, and protect/promote their market brand-name.

\section{Corporate Philanthropy, Ethics and (Re)insurance}

The concept of insurance as a promissory contract that compensates policyholders for economic loss fits closely with Carroll's (1979) three-dimensional view of CSR activities as overlapping economic, legal and ethical phenomena. Schwartz \& Carroll (2003) add that the incidence and scale of discretionary ethical (philanthropic) activities could be influenced by the economic interests of dominant constituents such as shareholders and board-level executives. This 'micro' pragmatic notion of corporate philanthropy, reflected for example, in agency theory, contrasts with 'macro' perspectives that views corporate philanthropy, particularly in publicly visible organizations, as satisfying societal expectations of 'desirable' ethical behavior and moral legitimacy (Suchman, 1995). Therefore, the decision of (insurance) firms to (re)insure and simultaneously donate to charitable organizations could help 'harmonize' the interests of key stakeholders (e.g., investors, managers and policyholders) with society's expectations of legitimate CSR behavior. Therefore, the concepts of corporate philanthropy, risk management and ethics are inextricably bound within the stakeholder constitution of organizations.

\section{Stakeholder Theory and (Re)insurance}

To frame our research, we draw on strategic stakeholder theory - an established analytical framework in organizational management and business ethics literature (Phillips, Freeman \& Wicks, 2003). Stakeholder theory emphasizes the pivotal role of the board of directors in interacting with stakeholders and balancing their (often conflicting) claims to 
ensure that the firm is financially successful and remains a 'going concern' (Freeman, 1984). In fact, Walls et al. (2012, p. 904) state that a strategic stakeholder perspective can help researchers to ". . . investigate the very real and inseparable tensions between a firm's financial and social demands." El Akremi, Gond, Swaen, De Roeck \& Igalens (2016) further emphasize that CSR-type decisions are context-specific, and reflect stakeholders' economic and social expectations. Additionally, Dewing \& Russell (2008) note that the FSMA (2000), which regulates the governance and management of financial services firms, including insurers, is unique in the UK in that it is designed specifically to safeguard and balance the economic interests of plural stakeholders rather than just shareholders.

Such scholars as Moore (2001), Laplume et al. (2008), and Chiu \& Sharfman (2011) advocate that strategic stakeholder theory can be also provide a useful basis for conducting CSP research as it highlights how firms legitimize their relations with multiple stakeholders through CSR activities such as charitable giving. This is particularly apt in the case of this study as the multiple stakeholders of insurance firms have competing but overlapping economic and political goals (Bhambri \& Sonnenfeld, 1988). Cole, McCullough, Semykina \& Sommer (2011) add that in the insurance industry, salient stakeholder groups have a strong mutual interest in monitoring and controlling the risk-taking activities of insurance managers in order to ensure future solvency and the protection of their contractual claims. Agle et al. (1999) conceptualize the salience of firms' stakeholders in terms of their power (financial and political), legitimacy (legal and moral), and urgency (societal and economic). This is a useful analytical benchmark in the context of the present study as these three traits characterize insurance industry stakeholders and can be optimized using reinsurance. In a finance context, Navarro (1988) argues that corporate giving helps increase revenue (e.g., by promoting the firm's brand-name), lower costs (e.g., of government enforcement actions), and saves taxes (e.g., by timing donations when marginal tax rates are high). However, in the insurance industry, reinsurance can achieve such strategic objectives more cost-effectively than philanthropy. Moreover, as reinsurance reduces insolvency, underwriting, and other financial risks in insurance firms, it concomitantly enables managers to protect the interests of less immediately powerful stakeholder groups, such as future generations of policyholders and minority shareholders (Cole et al., 2011). Such attributes are clearly important in a 'trust and relationship' business like insurance.

Stakeholder analysis could also explain the nature of a potential substitutive relation between philanthropy and reinsurance. Indeed, some (e.g., larger and multiproduct) insurers may make modest investments in social projects as well as reinsure if the economic payoffs 
from such philanthropic endeavours exceed the costs (e.g., by generating new business). The positive net present value (NPV) of such an investment in 'white-washing' could have wider stakeholder benefits beyond merely increasing value for shareholders. In contrast, other (e.g., small and niche) insurers are likely to have a less diversified customer-base whose economic interests are better served solely by purchasing reinsurance ${ }^{2}$. Therefore, stakeholder theory implies that differences in the reinsurance-philanthropy relation across insurance firms not only reflects the relative cost-effectiveness of reinsurance and CSR-type activities as strategic risk management options but also benefits a broader constituency of economic, social and political interests.

Given the importance of reinsurance to the insurance industry, reinsurers are clearly important stakeholders for insurance firms (Cole et al., 2011). As a result, reinsurers could explicitly take societal legitimacy and other benefits of philanthropy into account in assessing the business (e.g., litigation) risks associated with their partnership with insurance firms. For example, by promoting public trust and market confidence - the essential ingredients of insurance - a prominent philanthropic stance could help an insurer to mitigate a decline of future free cash flows and/or increase in the costs of capital arising from financially damaging events such as a serious breakdown in corporate governance. To the extent that CSR-induced free cash flow generation and/or reputational capital protection reduces the risks of financial distress and/or bankruptcy for insurers then stakeholders other than reinsurers - for example, investors, policyholders, and industry regulators - could also value philanthropy. The legislative and regulatory structure of the UK insurance industry means that insurers are exposed to a high risk of litigation not only as a result of contractual dispute (e.g., policy mis-selling) but also statutory non-compliance (e.g., inadequate capital maintenance). According to Koh et al. (2009), firms operating in highly litigious industries are, in theory at least, more likely to benefit from 'positive moral capital' arising from CSR activities as it tempers the severity of ex-post sanctions from stakeholders in the event of a major shock event such as a high profile legal dispute. On the other hand, reinsurance can provide pragmatic (economic) and moral (reputational) legitimacy plus lowered exposure to socio-political risks for the salient stakeholders of insurance firms. Therefore, the stakeholders of insurance firms are likely to require the board of directors to strategically prioritize reinsurance over philanthropy.

Strategic stakeholder theory also fits comfortably with recent research that links the resource allocation function of corporate governance with CSR strategy (e.g., see Hambrick, Werder \& Zajac, 2008; Lan \& Heracleous, 2010; Harjoto \& Jo, 2011). Godfrey et al. (2010), 
Koh et al. (2014), and others further contend that reputational insurance protection through CSR engagement can be particularly important in competitive environments, such as the UK's non-life insurance market, where customer switching costs and barriers of entry/exit tend to be low by international standards (Webb \& Pettigrew, 1999). It is against this stakeholder theory backdrop that we now turn in developing our research hypotheses.

\section{HYPOTHESES DEVELOPMENT}

\section{Reinsurance-Charitable Donations Relation}

As corporate philanthropy and reinsurance can, as noted earlier, conceivably perform similar strategic functions in alleviating market imperfections (e.g., information asymmetries) between an insurer's top management and its stakeholders, a substitutive (albeit non-equivalent) relation could exist between the decision to buy reinsurance and whether or not to engage in charitable giving. We argue that whilst CSR activities (e.g., philanthropy) and corporate (re)insurance serve the same strategic objective functions - namely, the maintained resilience and sustainability of the business - they are non-equivalent substitutes as the mechanism by which these two risk management options achieve these strategic goals will be different. For example, philanthropy could at one level, signal narrow (e.g., local community) stakeholder involvement, while reinsurance promotes financial stability that benefits a broader constituency of investors, policyholders, regulators, amongst others. Indeed, in the UK's insurance industry the strategic role of reinsurance is underscored by industry regulation and statutory solvency maintenance requirements (Upreti \& Adams, 2015). On a more broader level, philanthropy (e.g., the sponsorship of medical research) can benefit multiple stakeholders at both a national and international level, and so have wider public appeal and more extensive brand development value (El Akremi et al., 2016).

Koh et al. (2014) further suggest that risk management tools such as (re)insurance are not strictly equivalent to the intrinsic insurance qualities of CSR-type activities because the former are based on explicit contracts enforceable in law, whilst the latter are based on the intangible goodwill of stakeholders. However, we argue that CSR-type activities can be viewed as examples of multi-period implicit contracts between a firm and its constituents. These less formalized contracting arrangements could nevertheless be the subject of legal dispute - for example, take the case of a firm operating in the extractive sector reneging on a CSR commitment to invest in environmental protection - a decision that then results in severe economic losses and social disruption in the event of catastrophe (e.g., a major flood). If the firm's stakeholders challenged such a 'broken CSR promise' in a court of law, judgement could affect the scope and/or scale of insurers' liabilities under insurance contracts 
written with the firm, and in turn, possibly limit their ability to fully reclaim financial losses under reinsurance treaties.

There are two main functions of reinsurance in insurance markets (and indeed, for insurance in general industrial settings). First, reinsurance helps instil ex-ante confidence in an insurer's financial viability amongst stakeholders thereby enabling it to grow/maintain product-market share. Second, reinsurance can enable an insurer to stabilize period earnings and reduce the risk of financial distress/bankruptcy ex-post a loss event (Abdul Kader et al., 2010). As a brand protection strategy, investment in CSR activities likewise performs ex-ante and ex-post risk mitigation (Koh et al., 2014). Whilst reinsurance is extensively used in the non-life insurance industry (Froot \& O'Connell, 2008), it could nonetheless represent an opportunity loss to shareholders and other constituents unless it preserves and/or adds economic value to the insurance firm. Therefore, the board of directors is likely to prioritize the strategic decision to reinsure since it optimally protects the interdependent interests of the full constituency of stakeholders against the risk of financial distress/bankruptcy over an investment in corporate philanthropy that may only benefit a narrow constituency (e.g., see Lan \& Heracleous, 2010). This reasoning suggests a substitutive (negative) relation between reinsurance and the corporate decision to donate to charitable causes, and the amount of money contributed. Consequently:

Hla: Ceteris paribus, there is a negative relation between reinsurance and the decision to make donations.

H1b: Ceteris paribus, there is a negative relation between reinsurance and the amount donated.

On the other hand, the nature of the reinsurance-corporate donations relation could be complementary (positive). Insurers use reinsurance as a claims contingent capital alternative to holding (costly) equity and reserves (Abdul Kader et al., 2010). This has three main economic advantages for insurance firms. First, reinsurance tends to be more costeffective and easier to secure than equity capital (e.g., due to lower frictional and supply costs). Second, reinsurance can help managers stabilize period earnings and reduce future taxes - particularly under the progressive corporate tax codes that exist in most developed economies, including the UK and US. Third, reinsurers provide ancillary risk management services (e.g., loss prevention advice), which can add 'real value' for primary insurers especially those operating in new and/or highly specialist segments of the market (Upreti \& Adams, 2015). These strategic benefits of reinsurance could provide the free cash flows and contingent capital provisions necessary for insurers to not only engage in discretionary 
philanthropic activities such as charitable giving that advantage specific constituents (e.g., local communities), but also influence the level of investment in CSR projects that realize benefits for a much broader range of stakeholders at both the national and international scales.

Reinsurers, as key stakeholders could also be motivated to encourage philanthropy amongst their primary insurance clients as it could help them increase future rates of new business growth, improve the public visibility of the corporate brand, and/or minimize the risk (and cost) of regulatory intervention (Hsu, 2012) ${ }^{3}$. Indeed, recent adverse media publicity affecting the insurance industry in the UK and elsewhere - for example, with regard to product mis-selling, disputed insurance claims, and unclear and disputed contractual terms (Kvalnes, 2011) - could stimulate reinsurers to advise and encourage their primary insurance partners to donate to charitable causes in order to generate goodwill with other economically and/or politically influential stakeholders, such as investors and industry regulators. Such a strategy could be particularly beneficial for insurers entering new product-markets and/or operating in lines of business (e.g., pensions mis-selling) that have been subject to adverse media attention. Therefore:

H2a: Ceteris paribus, there is a positive relation between reinsurance and the decision to make donations.

$H 2 b$ : Ceteris paribus, there is a positive relation between reinsurance and the amount donated.

\section{Moderating-Effects of Board Composition}

Recent management research (e.g., Jia, 2013, 2014) stresses the importance of testing for potential moderating-effects in predicted relations between variables. Harjoto \& Jo (2011) note that board composition can particularly influence philanthropy as stakeholder and strategic risk management are integral to effective corporate governance. Accordingly, in our multivariate analysis we use, and briefly motivate, six variables identified as important in prior CSR studies to capture the moderating-effects of board composition on the relation between reinsurance and charitable giving.

Outside Directors: To promote their 'human capital' value, independent outside directors on the board could attempt to balance the conflicting resource claims of different constituents beyond the narrow goal of maximizing shareholders utility by reinsuring and engaging in philanthropy (Ibrahim, Howard \& Angelidis, 2003). Moreover, in promoting earnings stability reinsurance could help insurers to accumulate the necessary resources needed to fund philanthropic projects and thus promote the public reputations of board 
outsiders as prudent and socially responsible managers. This is likely to be an important motivation in a public trust orientated and regulated business like insurance Therefore:

H3a: Ceteris paribus, there is a positive moderating relation between reinsurance and proportion of outsiders on the board and the decision to donate/amount donated.

CEO-Chairman Separation: Separating the CEO from the Chairman functions could reduce the degree of CEO power on the board and so better serve the socio-economic interests of a broader spectrum of stakeholders (Combs, Ketchen, Perryman \& Donahue, 2007). Reinsurance, in conjunction with separating the CEO and Chairman functions, could also help reduce the adverse effects of risk-taking and maintain financial stability. Again, such qualities are particularly important in a highly regulated and public trust-dependent industry such as insurance. This could increase the propensity of insurance firms to both reinsure and donate to charitable causes. As a result:

H3b: Ceteris paribus, there is a positive moderating relation between reinsurance and CEO-Chairman separation and the decision to donate/amount donated.

Inside Ownership: Owner-managers could engage in reinsurance and charitable giving in order to fulfil personal welfare objectives and/or assuage the claims of other stakeholders thereby complementing the link between reinsurance and philanthropy (Coffey \& Wang, 1998). For example, reinsurance could allow owner-managers to concomitantly mage assumed risks and promote a philanthropic public profile - again a quality that is likely to be particularly important in a public trust and risk protection important business such as insurance. Accordingly:

H3c: Ceteris paribus, there is a positive moderating relation between inside ownership and reinsurance and the decision to donate/amount donated.

CEO Bonus plans: Mahoney \& Thorn (2006) report that CEO bonuses can facilitate CSR engagement as they can reduce the potentially deleterious reputational consequences arising from public media criticism of perceived excesses in executive compensation. By improving corporate solvency and signalling prudential management reinsurance could therefore limit the likelihood that CEO incentive compensation will attract adverse public criticism. Consequently:

H3d: Ceteris paribus, there is a positive moderating relation between CEO bonus plans and reinsurance and the decision to donatelamount donated.

Board-Level Female Directors: Prior studies (e.g., Brammer, Millington \& Pavelin, 2009) suggest that female directors tend to be behaviorally inclined to precautionary 
strategies, and more sensitive to balancing the needs and requirements of different stakeholders of the firm than their male counterparts. Therefore, the female board members of insurance firms could actively promote charitable giving and risk reduction strategies such as reinsurance as part of a prudent and precautionary approach to business management. Such reasoning implies:

H3e: Ceteris paribus, there is a positive moderating relation between the proportion offemales on the board and reinsurance and the decision to donate/amount donated.

Board-Level Financial Experts: The presence of professional finance experts (e.g., actuaries and/or accountants) on the board could positively influence charitable giving - for example, as a result of CSR guidelines issued by their respective professional bodies (e.g., the UK's Association of Chartered Certified Accountants CSR Report (2011)). The purchase of reinsurance could also enable professionally qualified financial experts on the boards of insurance firms to realize both CSR-related goals and protect the interest of key stakeholders such as policyholders, investors and industry regulators. As a result:

H3f: Ceteris paribus, there is a positive moderating relation between the proportion of financial experts on the board and reinsurance and the decision to donate/amount donated.

\section{RESEARCH DESIGN}

\section{Data}

A balanced panel sample of 77 UK-based non-life insurance insurers (924 data points) for which complete time-series data exist for the 12 years 1999 to 2010 are used to test our hypotheses ${ }^{4}$. CSR decisions can be given different strategic emphasis from one year to another depending on factors such as changes in managerial priorities and firms' financial condition (Godfrey et al., 2010). Therefore, we consider that a longitudinal analysis is an appropriate approach to use in the current study. Moreover, the size of the panel data set was restricted in that statutory firm-level financial data had to be hand-matched with corporate donations and demographic governance details that were not always readily available for some insurers over the analysis period.

Our data derive as follows: (a) insurance data were obtained from Standard \& Poor's Synthesys insurance companies' database, which is sourced from the regulatory returns submitted annually by UK insurance companies to the then industry regulator - the Financial Services Authority (FSA) ${ }^{5}$; and (b) data on governance structures and corporate donations were obtained from the annual reports and accounts, internet and charity sources, and UK 
insurance company directories. In the case of composite (life and non-life) insurers in our panel sample that only report group-level donations, the non-life insurance subsidiary's annual share of charitable giving is estimated on a pro-rata of its contribution to annual group gross premiums written. The timeframe covered by our study includes the years from when CSR started to be of direct strategic interest to UK insurers following some high profile corporate failures to the time just after the $2007 / 8$ global financial crisis ${ }^{6}$. We conduct our analysis at the UK insurance firm-level as this is the relevant decision-making unit for financial reporting, statutory solvency monitoring, and most discretionary decisions (e.g., on CSR issues) that affect the local market. Our panel sample of 77 firms constitutes roughly $25 \%$ of non-life insurers actively operating in the UK over our period of analysis, and comprises a mix of firms of varying size, ownership, and financial structure. The majority of insurers in our data set $(n=67 / 87 \%)$ are stock companies of which roughly one-third are small mono-line insurers that specialize in niche segments of the market (e.g., personal lines). Furthermore, most stock insurers in the data set $(n=60 / 90 \%)$ are non-listed entities. However, the preponderance of stock over mutual forms of organization, and non-publicly quoted stock insurers in our data set precludes us from controlling for organizational form and public/private listing status in our analysis.

\section{Main Variables of Interest}

Like some previous studies (e.g., Brown, Helland \& Smith, 2006), we treat direct (cash) donations as our dependent measure of corporate philanthropy. This measure excludes philanthropic benefits-in-kind to charities such as tax advice, and indirect charitable contributions such as payments made under voluntary employee pay-as-you-earn schemes ${ }^{7}$. Donations to charitable and altruistic (as opposed to promotional) community causes are a quantifiable aspect of corporate philanthropy, which in the UK can be obtained or estimated from companies' annual reports and other public media (e.g., corporate brochures and charitable organizations) (Brammer \& Millington, 2003, 2004, 2008) ${ }^{8}$. Charitable contributions are also an important form of discretionary corporate expenditure and they are often viewed as a prime and integral aspect of CSR activity (Masulis \& Reza, 2015). Brammer \& Millington (2004, pp.1412-1413) further argue that because of their lower susceptibility to measurement error (unlike multidimensional CSR indices) charitable donations are ". . . an excellent mechanism through which to observe and analyse the interface between stakeholders, corporate strategy, and CSR." Peloza (2006) also notes that corporate philanthropy has broad socio-economic and environmental impacts that can 
directly create business benefits as well as build 'moral capital' for the donator. For example, in the context of the insurance industry, support for community land improvements could have environmental benefits such as lowering the risk of insurance losses due to flooding, coastal erosion, and/or storm damage. In this way, charitable donations can correlate closely with broader CSR engagement. Moreover, unlike some other countries, such as the US, charitable donations in the UK tend to be made directly by companies rather than 'hidden' via intermediary charitable foundations (Brammer \& Millington, 2008). This institutional advantage circumvents the potentially confounding effects of reduced shareholder/stakeholder accountability and agency problems that can arise when board-level executives use corporate resources to fund foundation charities with which they are personally affiliated (Masulis \& Reza, 2015).

We acknowledge that whilst a precise indicator, corporate giving is a single dimension of the multifaceted CSP profile of a firm (Jo \& Na, 2012). However, as noted by several scholars (e.g. Entine, 2003; Laplume, Sonpar \& Litz, 2008; Krüger,2014) composite CSR indices that derive from multiple data sources collected and compiled by CSR ratings firms such as Kinder, Lydenberg, Domini \& Co Inc. (KLD) have major limitations. For example, despite claims of construct validity (e.g., Godfrey et al., 2009), many others (e.g., Krüger, 2014) argue that aggregate CSR indices are highly susceptible to: (a) measurement error (especially when component scores are based on subjective sources such as interview evidence); (b) sample selection bias (e.g., KLD data only relate to US publicly listed firms); and (c) limited comparability when used in longitudinal and transnational contexts, particularly when non-overlapping samples are used. For these reasons, and on the grounds of precision, we use charitable donations as our preferred measure of philanthropy.

Our main independent variable of interest in this study is reinsurance - a commonly used hedging (balance sheet and earnings protection) tool on which data, unlike for corporate insurance, are publicly available in the UK and indeed, other insurance markets such as the US and some European countries. It is further pertinent to note that as a pure indemnity mechanism, reinsurance cannot be used for speculation (unlike other hedging instruments such as derivatives) (Zou \& Adams, 2008). This means that in using reinsurance data, our study provides a potentially robust and reliable test of the corporate philanthropy-risk management relation.

\section{Firm-Related Control Variables}

Prior stakeholder theory-based studies (e.g., Adams \& Hardwick, 1998; Brammer \& Millington, 2008; Barnett \& Salomon, 2012) indicate that in the context of exploring 
corporate donations firm-specific factors can also be relevant. Therefore, we control for seven firm-related variables in our analysis: (a) firm size; (b) ownership structure; (c) managerial (insider) ownership; (d) leverage; (e) profitability; (f) product-line and (g) firm age. We expect concentrated ownership structure and leverage to be inversely related to the decision to commit to charitable giving, and the amount given. For example, dominant shareholders (such as pension funds) are likely to maximize their financial claims in order to meet obligations to their constituents (e.g., pensioners), whereas highly levered (cash constrained) insurers are less likely to donate to charitable causes). The other firm-specific variables are predicted to be positively related to the incidence and level of corporate charitable donations. For example, large, well-established, and profitable insurers are likely to have the 'slack' resources to contribute to charitable causes, while owner-managers, in conjunction with their reinsurance partners, may engage in philanthropy to raise the public visibility of the corporate profile and so increase future rates of new business. Multi-product line insurers tend to have a more diversified customer-base and broader stakeholder constituency than niche (e.g., personal lines) insurance providers, and as such, more likely to engage in philanthropy. Details of the measurement of our variables, and their predicted signs, are given in Table $1^{9}$.

\section{[INSERT TABLE 1 HERE]}

\section{Modelling}

As in previous CSR research (e.g., Harjoto \& Jo, 2011), we model the charitable donation-reinsurance relation using a two-step regression procedure. A separate analysis of the corporate decision to make charitable donations and the amount donated is necessary as it is not possible to formulate and test a single model that simultaneously captures both firststage and second-stage strategic choices. The first 'participation' model (random-effects bivariate probit) tests the decision to donate or not, and the second 'volume' model (a leftcensored tobit) estimates the amount donated. ${ }^{10}$ Another rationale for adopting our two-part modelling approach to the 'participation' and 'volume' decisions is that it could reveal insights into the focal firm factors (e.g., size and structure) that could influence the respective philanthropic and reinsurance decisions of managers. It is also possible that reinsurance could be linked indirectly with charitable giving through its mediation with other financial variables such as profitability. Therefore, we applied Heckman's (1979) two-step sample selection correction procedure which includes the inverse 'Mills ratio' correction $(\lambda)$ in the second-stage 'volume' model. 
In the 'participation' model the dependent variable (DONDUM) is binary, taking the value 1 if an insurer donates to charities, and 0 otherwise. Our choice of the probit model over other binary dependent variable models (e.g., logit) is based on the assumption that the indicator variable of interest (in our case charitable donations) is not random but a deliberate strategic decision conditioned by probabilistic rather than other (e.g., log-normal) distribution assumptions (Greene, 2003). The random-effects estimator is preferred as some of our variables (notably reinsurance) show little within-firm variation over the panel period (1999 to 2010) (Greene, 2003). To check the validity of the random-effects estimator we conducted a Hausman specification test (Hausman, 1978), under the null hypothesis that unobservable firm-effects are serially uncorrelated with the explanatory variables thus minimizing the risk of sample selection bias. The Hausman test did not reject the null hypothesis thereby supporting the random-effects specification. We also control for unobserved firm-related heterogeneity (e.g., differences in managerial ability) in the 'participation' model since failure to do so could lead to biased coefficient estimates and endogeneity concerns (Heckman, $1981)^{11}$. Our random-effects probit model is thus:

$$
P_{i t}^{*}=X_{i t}^{\prime} \beta+v_{i t}
$$

In equation (1), $P^{*}$ denotes the unobservable factors influencing an insurer's propensity to donate, or not donate to charitable causes. We assume that the incidence of charitable donations is observed only when the insurer's propensity to donate exceeds zero. We thus have: $P_{i t}=1$ if $P_{i t}^{*}>0$ and $P_{i t}=0$ otherwise; $X_{i t}^{\prime}$ is a vector of time-varying explanatory variables (defined in Table 1); $\beta$ is a vector of the parameters to be estimated; and $i=1,2, \ldots$ - $n$ indexes the sample observations for the period $t$ investigated. To capture unobservable effects (e.g., managerial CSR experience) on the 'participation' decision we decompose the error term $v_{i t}$ in (1) as:

$$
v_{i t=} \alpha_{i}+u_{i t}
$$

In equation (2), $\alpha_{i}$ denotes unobserved heterogeneous firm-effects that are time-invariant, while $u_{i t}$ represents unobserved firm characteristics that do vary across time; we also treat $\alpha_{i}$ as random. The random-effects probit model is estimated using the maximum likelihood procedure under the condition that: $u_{i t} \sim N\left(0, \sigma_{u}^{2}\right), u_{i t}$ are independent of vector $X$; and $\alpha_{i} \sim N\left(0, \sigma_{\alpha}^{2}\right)$, the $\alpha_{i}$ are independent of the $u_{i t}$ and vector $X$. To gauge the sensitivity of the explanatory variables to changes in the predicted probability of the corporate donation decision, the coefficient estimates in the probit model are transformed to represent the 
marginal-effects evaluated at the means of the regressor variables computed from averaging individual observation responses (Hoetker, 2007). Similarly, marginal-effects are also evaluated against median values given the skewed distribution of some variables (e.g., firm size) in the panel data set. The marginal-effects for the dummy variables are calculated as the discrete change in the dependent variable as it changes from 0 to 1 (Greene, 2003).

The tobit ('volume' decision) model assumes that the dependent variable $\left(Y^{*}{ }_{i t}\right)(D O N)$ is a non-limited (positive) observation truncated at 0 . That is:

$$
Y^{*}{ }_{i t}=\beta^{*} X_{i t}+\lambda+u_{i t}\left(\text { where } u_{i t}-N\left(0 \delta^{2}\right)\right)
$$

In equation $3, \beta^{*} X_{i t}$ is a vector of the explanatory variables (as defined in Table 1 ); $\lambda$ is the inverse Mills ratio; and $u_{i t}$ is a normally distributed error term that captures random influences on the variables to be estimated (Greene, 2003).

\section{EMPIRICAL RESULTS}

\section{Descriptive Statistics}

We report the descriptive statistics for our panel of insurance firms in Table 2 (panels $\mathrm{A}$ and $\mathrm{B})$.

\section{[INSERT TABLE 2 HERE]}

The average annual value of charitable donations $(D O N)$ for our panel sample of UK non-life insurers given in panel $\mathrm{A}$ is $£ 50,000$; this figure is low as it is less than $1 \%$ of average net annual profit (before interest and tax) and only about $4 \%$ of average yearly selling expenditures over the period of analysis (1999 to 2010). Moreover, just over $40 \%$ of the insurers in our panel data set do not to donate to charitable organizations at all. These observations are consistent with Brown et al. (2006) who report that despite being highly regulated and publicly salient entities, financial services firms tend to invest less (in relative and absolute terms) in CSR activities than other firms - especially those operating in high 'externality impact' sectors such as mining and petro-chemicals. The notes to Table 2 also indicate that of our panel sample, 35 insurers (46\%) consistently did not donate to charitable causes over time, while larger more visible insurers regularly made charitable contributions though the sums involved varied each year. This observation supports Chiu \& Sharfman's (2011, p. 1560) conjecture that CSR activities will in all likelihood ". . not be uniform . . across firms within industries because firms . . . vary in the amount of attention that they attract." The insurers in our UK panel data set on average cede just over a third of their annual premiums to their reinsurance partners compared with a mean of $16 \%$ of reinsured 
annual premiums reported for the UK's life insurance industry by Abdul Kader et al. (2010). The lower amount of risk retention (greater the amount reinsured) in our sample reflects the greater unpredictability of the risks underwritten in non-life insurance compared with the life insurance sector where relatively more accurate actuarial pricing and reserving practices are more prevalent (Froot \& O’Connell, 2008).

The other financial characteristics of the sample given in Table 2 (panel A) not surprisingly indicate a large variation in our sample of insurance firms in terms of firm size (SIZE), profitability (PROFIT) and age $(A G E)$. Given the highly regulated nature of the UK's insurance industry (Webb \& Pettigrew, 1999), the premium-to-surplus ratios (LEV) for our sample of insurance firms suggest that despite a few cases of low leverage (minimum $=0.53$ ) overall mean/median levels of solvency were satisfactory during the period of analysis (i.e., $>1.0)$. The descriptive statistics for product-line (P-LINE) also show that the insurers in our panel sample range from multiproduct providers to niche operators.

The board composition statistics indicate an average board size of seven members. This figure is fairly consistent with the average board size of eight directors reported in Hardwick, Adams \& Zou (2011) for the UK's life insurance industry over the period 1994 to 2004. Additionally, the majority of board members in our panel data set (mean $=55 \%$ ) are independent outside directors as recommended by the Cadbury Report (1992). Also consistent with the Cadbury Report (1992), the vast majority (mean $=92 \%$ ) of the insurers in our sample separate the CEO and Chairman functions. The mean proportion of board members who are qualified finance professionals (accountants and actuaries) was $28 \%$ over the period of our analysis. The observed presence of board-level financial experts is as we expected given the technically complex nature of non-life insurance business. However, the average proportion of females on the board $(G-M I X)$ during our sample period is low (mean $=3 \%)$.

To get more of a handle on the characteristics of those in insurers in our data set that engage in philanthropy and those that do not, in panels B and C of Table 2 we split our panel sample between charitable donators and non-donators. From panels B and C it is evident that insurers contributing to charitable causes are bigger and less heavily reinsured. This suggests that compared to small insurers, large insurers are likely to have the resources tro invest in philanthropy and more effectively lower their risk through diversification. In addition, we conducted t-tests (for metric measured variables) and Wilcoxon-Mann Whitney U tests (WMWU) and Chi-square $\left(\chi^{2}\right)$ statistics (where variables are categorical) to determine whether statistically significant differences exist in the mean values for the organizational 
characteristics of charitable donators and non-donators in our data set. This procedure is particularly useful given the presence of some extreme values in the distribution of the panel data. The statistical tests of mean difference are reported in Table 2, panel D. They show that statistically significant differences exist between the means of all our explanatory variables (at $\mathrm{p} \leq 0.05$, two-tail, or better). Most notably, insurers that donate to charities tend to be larger, more profitable, and more established firms, while insurance firms that do not contribute to charitable causes are generally smaller and more highly reinsured entities. These results are consistent with the descriptive statistics reported in panels B and C, and again hints strongly at firm size/age/profitability-effects influencing the decision to engage in corporate philanthropy.

\section{Correlation Analysis}

Table 3 reports the correlation coefficient matrix for the variables (including interaction terms) used in the study. Table 3 confirms the expected positive firm size/board size, age, and profitability influences, and negative leverage effects on the donation decision and insurers' financial commitment to charities. Statistically significant and positive associations between the donation decision/amount of charitable contributions also exist between insider ownership plus the proportion of outsiders and women on the board (at $\mathrm{p} \leq 0.05$, two-tail or better). In addition, negatively significant associations are found between corporate donations and reinsurance (our main variable of interest) and as we previously predicted, ownership structure. Also, as expected donations are positively and significantly linked when reinsurance interacts with inside ownership and the proportion of female directors on the board. However, contrary to expectations when CEO incentive compensation interacts with reinsurance the moderating effect is negative suggesting that the 'risk reduction -effect' of reinsurance reduces the need for CEOs to use philanthropy to reduce the possible adverse public effects arising from the disclosure of CEO bonuses and other benefits. However, some of the high and statistically significant correlation coefficients reported in Table 3 raises the possibility of multicollinearity. Therefore, we follow Kennedy (2003) and derive variance inflation factors (VIFs) for the explanatory variables ${ }^{12}$. The VIF for BSIZE (22.35) - the only VIF computed - was greater than the 'acceptable' threshold value of 10. Therefore, we excluded BSIZE from our multivariate analysis to mitigate possible bias arising from multicollinearity. ${ }^{13}$

[INSERT TABLE 3 HERE] 


\section{Multivariate Analysis}

\section{Probit Results}

The results of the probit analysis, including the mean/median evaluated marginaleffects, are reported in Table 4 . Table 4 gives three models beginning with the base-line model 1 (excluding reinsurance), then adds in a step-wise manner reinsurance with the board composition variables and interaction terms in models 2 and 3.

\section{[INSERT TABLE 4 HERE]}

Table 4 indicates that consistent with $H I a$, reinsurance (REINS) is negatively related to the decision to engage in charitable giving (at $p \leq 0.01$, one-tail) in models 2 and 3 . This observation suggests that compared with reinsurance, CSR activities do not perform a significant strategic risk management function in the UK's non-life insurance industry. These results support the observations made by other researchers (e.g., Brown et al., 2006) that charitable giving tends to be a lower strategic priority in the financial services sector compared with industries like mining whose operations can generate obvious negative externalities. The marginal-effects computed at the mean/median values (panel B) indicate that when incorporating other board-level factors (but not the interactions) in model 2, reinsurance reduces the probability of corporate giving by $341 \% / 72 \%$. In other words, reinsurance exhibits a strong substitutive relation with the corporate decision to donate to charities.

The full probit results (given in models 1 to 3 of Table 4) confirm our earlier correlation coefficient analysis (Table 3) in that they show that the donation decision is directly related to the size $(R(S I Z E))$ and age $(R(A G E))$ of insurers (at $\mathrm{p} \leq 0.01$, one-tail) even when rank transformations are applied to limit the potentially confounding effects of extreme values. These findings make sense intuitively as large firms usually have more discretionary funds to invest in pro-social projects than small firms (Brammer \& Millington, 1998). As predicted, ownership concentration $(O W N)$ is found to be negatively associated with the decision to give to charitable causes (at $p \leq 0.01$, one-tail) when other board-level factors come into play (see Table 4, model 3). This suggests that as expected, dominant investors could counter altruistic initiatives by some board members (e.g., outsiders) in an attempt to maximize their private claims on the firm's free cash flows. Moreover, insider ownership (INSIDE) is, as we expected, positively related to the decision to engage in corporate philanthropy in models 2 and 3 (at $\mathrm{p} \leq 0.05$, one-tail or better). This finding suggests that charitable contributions could help the owner-managers of insurance firms to increase the corporate brand-name and product-market share, and therefore enhance the value of their 
equity investment. Whilst 'correctly' signed, leverage ( $L E V)$ is not statistically significant in Table 4, models 1 to 3 .

In terms of our board-level governance variables, the propensity of insurers to donate to charitable causes is positively related to the proportion of outsiders on the board (OUTS), , and the presence of female directors $(G-M I X)$ (see models 2 and 3). These findings are statistically significant (at $\mathrm{p} \leq 0.05$, one-tail or better) and they accord with what we hypothesized in $H 3 a, H 3 b$, and $H 3 e$. Ostensibly, our observation regarding $G-M I X$ supports the often cited claim that in terms of their decision-making behavior, female directors tend to be more inclined to balance stakeholders' different interests and support CSR initiatives than their male counterparts (e.g., see Brammer et al., 2009). It is also interesting to note that all the CEOs in our panel data set - most of whom (84\% per Table 2, panel A) had bonus schemes in place - were male. We also observe that COMP is inversely related to the decision to engage in corporate charitable giving (at $p \leq 0.01$, two-tail). This finding is contrary to what was hypothesized $(H 3 d)$, and suggests that private wealth maximization predominates over social philanthropy amongst the CEOs in our sample of insurance firms. This finding also confirms recent survey evidence obtained by McKinsey (2015) from the US property-casualty insurance industry that indicates only a minority (30\%) of CEOs surveyed play a leadership role in charitable giving. The presence of financial expertise on the board $(P R O F)$ also reduces the probability of charitable giving (at $\mathrm{p} \leq 0.01$, one tail) in model 3 of Table 4; this finding is inconsistent with $H 3 f$. However, the median marginal-effects of these observed negative relations on the donation decision of COMP and PROF are fairly moderate at $11 \%$ to $10 \%$, respectively. Nevertheless, this observation runs contrary to prior research (e.g., Mahoney \& Thorn, 2006) that argues that the existence of board directors' bonus plans can promote CSR engagement and so enhance firms' franchise value and market brand-name. Rather our results support the view of other scholars (e.g., Coombs \& Gilley, 2005) who argue that CEOs are likely to be disinclined to support corporate philanthropy if it reduces payoffs on their bonus plans. Additionally, the negative coefficient estimate for $P R O F$ in models 2 and 3 of Table 4 is inconsistent with the notion that financial experts on the board are likely to be familiar with, and thus inclined towards, CSR-type activity and its disclosure in the annual report and accounts. However, in our probit analysis the effect of product-lines $(P-L I N E)$ on the corporate donations decision is not statistically significant at conventional levels of $5 \%$ or better in any of the models reported in Table 4.

We also included interaction terms in our probit analysis (in Table 4, model 3) given the potential moderating-effects of board-level governance on reinsurance (REINS) and the 
decision to donate to charitable causes (e.g., see Walls et al., 2012) ${ }^{14}$. Model 3 indicates that the corporate decision to engage in charitable giving is now affected positively by the existence of CEO bonuses (REINS $\times C O M P$ ) (at $\mathrm{p} \leq 0.01$, two-tail) and negatively (at $\mathrm{p} \leq 0.05$, two-tail or better) by the proportion of insider ownership (REINS $x$ INSIDE), and the proportion of female board members (REINS $x G$-MIX). The positive coefficient estimates for REINS $x$ COMP suggests that as reinsurance promotes the key strategic goals of corporate solvency and profitability (Abdul Kader et al., 2010), it can have a positive interactive impact on both the decision to give to charitable causes and CEO compensation. The statistically significant negative coefficient estimate for REINS $x \operatorname{INSIDE}$ (at $\mathrm{p} \leq 0.01$ ) suggests that the financial benefits of reinsurance reduce the need for manager-owners to donate money to charitable causes in order to mitigate business risks. Moreover, the statistically significant (at $\mathrm{p} \leq 0.05$, two-tail) and negative coefficient estimate for the interaction term REINS $x$ G-MIX hints that although potentially sympathetic to corporate philanthropy, female board members (recall most of whom in this case are outside directors) may in practice assign a higher strategic priority to solvency and risk management issues than they do to discretionary matters such as CSR investment. This could reflect a predominantly precautionary and self-interested approach to business strategy among outside directors collectively and female directors in particular. Perhaps somewhat controversially, these results imply that such board members are primarily concerned with protecting and promoting their 'human capital' value in the managerial job market than simply being innately altruistic in their support for charitable causes. The predominance of self-interest over altruism amongst board members irrespective of their demographic traits (e.g., gender) has also been reported in prior corporate governance research (e.g., see Brickley \& Zimmerman, 2010). Panel B of Table 4 indicates that the median marginal effects of the interaction of reinsurance with inside ownership and female directorships reduces the probability of donating to charitable causes by the substantive percentages of $54 \%$ and $36 \%$ respectively.

\section{Tobit Results}

The results of our tobit analysis are presented in Table 5 (models 1 to 3). In accordance with $H 1 b$ and the first-stage probit analysis reported in Table 4, the tobit results confirm that reinsurance (REINS) is inversely related to the amount donated to charities (at $\mathrm{p} \leq 0.05$ or better, one-tail). Furthermore, the mean-level marginal-effects reported in Table 5 suggest that in practical economic terms $£ 1$ spent on reinsurance reduces corporate charitable donations by between $4 \%$ and $17 \%$. The tobit results for our board-level variables are 
consistent both with what we hypothesized and the probit analysis. We also find that consistent with the earlier probit analysis, firm size $(R(S I Z E))$ and age $(R(A G E))$ directly influence the amount of charitable giving, while concentrated ownership structure $(O W N)$ and now leverage $(L E V)$ are negatively linked with the level of charitable contributions (at $\mathrm{p} \leq 0.01$, one-tail) as expected. The statistical significance of $L E V$ in the tobit analysis suggests that lowly levered insurers are more likely than their highly levered counterparts to have the spare resource capacity needed to engage in philanthropy. Models 2 and 3 of Table 5 also indicate that INSIDE is directly related not only to the propensity to donate but also with the financial amount donated (at $\mathrm{p} \leq 0.01$, one-tail). This suggests that contributing to charitable causes could benefit owner-managers (e.g., in terms of enhanced public reputation).

[INSERT TABLE 5 HERE]

Turning to the interaction terms in model 3, we find that consistent with the probit analysis, REINS $x$ INSIDE is negative and statistically significant (at $\mathrm{p} \leq 0.01$, two-tail). However, this is the only statistically significant interaction term in the tobit analysis and supports the view that risk mitigation benefits of purchasing reinsurance dilutes the incentives of owner-managers to donate large sums to charitable causes. We also observe that the explanatory power (McFadden's adjusted pseudo- $\mathrm{R}^{2}$ ) of our models in Tables 4 and 5 increases incrementally under the three regression model analyses carried out in the probit and tobit tests. This suggests that the incidence and propensity of corporate donations are influenced by reinsurance acting in a substitutive manner and conjointly with other boardlevel and firm-related factors. In addition, the inverse mills ratio $(\lambda)$ is statistically significant in all three models in the tobit analysis, which justifies controlling for selection bias in order to improve the consistency of the parameter estimates.

\section{DISCUSSION AND CONCLUSION}

Drawing a framework from strategic stakeholder theory and using UK non-life insurance firm-level panel data for the 12 years 1999-2010, we examine empirically the link between corporate charitable donations and the purchase of reinsurance and after controlling for the moderating-effects of board composition and the financial characteristics of insurance firms. We find that consistent with $H I a$ and $H 1 b$, reinsurance substitutes for charitable giving as it more cost-effectively satisfies the socio-economic and political interests of a broader constituency of major stakeholders. Our finding of a statistically significant negative relation between charitable donations and reinsurance also explains why financial services 
firms in general, and insurers in particular, are often viewed as poor contributors to CSR activities compared with industries (e.g., mining) that generate negative externalities (e.g., see Brown et al., 2006; Pharoah \& Walker, 2015; Zimmeck \& Walker, 2015). In this regard, our results challenge the view of Marquis \& Qian (2014) and others, that publicly prominent firms are more likely than other firms to engage in CSR-type activities. We also find that CEO bonus plans reduce the propensity of insurers to donate to charitable causes, although this effect may be ameliorated by the interaction of reinsurance in terms of the amounts donated. Additionally, we observe that firm size, age and insider ownership are positively linked in preliminary analyses to the corporate decision to contribute to charitable causes as well as the extent of such CSR investment. Preliminary tests incorporating board composition variables indicate a positive relation between the decision to contribute, and the financial amount of charitable contributions, and the proportion of outsiders and females on the board. However, negative interactive effect between reinsurance and the proportion of outsiders and females on the board and the corporate donations decision revealed by our probit analysis is interesting in that it suggests that risk management predominates the collective thinking of board members (including outsiders and female members) as it is critical to realizing the key strategic objectives such as solvency maintenance and earnings stability, and hence improved job security.

The main conclusion of this study is that philanthropy matters in a risk management sense only if the economic gains to stakeholders with definable and enforceable contracting/transacting claims on firms exceed the benefits of financial risk hedging mechanisms (such as (re)insurance). Our empirical evidence further implies that the strategic benefits of CSR investment in general, and charitable giving in particular, are likely to vary between firms and across industrial sectors depending on the different strategic risks and risk management tools/expertise that might, or might not exist. As a result, insights gleaned from our research could enable managers, investors and others to more critically evaluate the cost and benefits of CSR-type activities in the context of other risk management strategies. The results of our research could be extended to other parts of the financial sector (e.g., banking) where insurance and other risk hedging activities undermine strategic and operational decisions.

Our study could also provide a basis for examining the 'CSR-as-insurance' aspects of firms operating in non-financial sectors where the effective management of economic risks and stakeholders' interests are likely to be critically important - for example, as in extractive industries that are heavily engaged in the management of potential economic losses due to 
such business risks as environmental hazards and potential litigation. For example, prior studies (e.g., Koh et al., 2014) note that firms operating in industries (e.g., mining) with potential negative externalities of production are more likely to invest in philanthropy and wider CSR activities in order to mitigate the risk of litigation and loss of goodwill (franchise value) in the event of business mishap. Future cross-industry research could therefore usefully extend the research agenda by examining the extent to which investment in philanthropy and other aspects of CSR behavior are influenced by the use of more conventional (formal) risk management practices (e.g., insurance) and other firm-specific and sector-based factors. For example, firm-level variations between CSR investment and corporate insurance spending could reflect differences in asset insurability between firms operating in different industries such the technology sector where growth options arise from intangible assets (e.g., know-how), and those industries (e.g., oil and gas) whose market value is highly dependent on the effective use of physical assets.

We consider that our study makes three major contributions to the literature. We believe this study is the first to test empirically the influence of reinsurance on the decision of insurers to contribute to charities, and the amount donated. This is particularly apt in the case of the insurance industry, which is an important industrial sector in most developed countries (Hsu, 2012). Brammer \& Pavelin (2006) observe that the median annual value of direct cash and in-kind philanthropic contributions (e.g., community involvement) by the UK's leading companies is only $0.8 \%$ of reported pre-tax earnings. Zimmeck \& Pharoah (2015) further report that in 2012/13 charitable contributions made by UK insurers was at $£ 9.2$ million (US\$14.2 million) less than one-tenth of that donated by UK banks in the same period. The modest contributions to charitable causes observed amongst insurance firms support the observation of Muller, Pfarrer \& Little (2014) that the criteria that inform boardlevel decisions to engage or not engage in philanthropy are not clear from the extant literature. These statistics further underscore a fundamental question highlighted by researchers such as Moore (2001), Jo \& Harjoto (2011), Barnet \& Salomon (2012), amongst others, and that is: does it pay companies to do good? In the context of the present study, two additional questions arise as follows: (a) given their public visibility why are charitable donations by insurers as a proportion of earnings so low relative to other sectors? and (b) does reinsurance influence the strategic decision of insurers to engage in philanthropy? Our observation that reinsurance is a (non-equivalent) substitute for corporate charitable giving in UK non-life insurance firms addresses these questions. As insurance is an all-pervasive and significant item of discretionary risk management expenditure in the corporate sectors of 
developed economies that typically exceed annual dividends by a factor of up to $40 \%$ (Lin, Lin \& Zou, 2012), our results can, as noted earlier, be extended to other financial and nonfinancial sectors that engage in substantial risk hedging, and so have a broader appeal to management scholars.

Second, our research sheds light on another theoretically-motivated question often asked by scholars (e.g., Jensen, 2002) and that is: which of a firm's stakeholders matter the most? Several studies in the management literature (e.g., Agle, Mitchell \& Sonnefield, 1999; Kaler, 2003; 2006) highlight the tensions that academics and practitioners face in conceptualizing and prioritizing how a firm's scarce resources should be allocated among a competing hierarchy of stakeholder claims. However, (re)insurance not only allows (insurance) firms to harmonize the competing interests of primary stakeholders with direct (explicit) contractual claims on insurance firms (e.g., policyholders, investors and managers), but also benefit secondary (normative) groups, such as the wider public, that may have overlapping (implicit) moral claims arising from a 'shock' event. This intuition contrasts with the study of Godfrey et al. (2009), which finds that 'CSR-as-insurance' primarily benefits secondary rather than primary stakeholders, and suggests that compared with financial risk mitigation strategies such as (re)insurance, investment in CSR-type activities is of secondorder strategic importance. In this regard, the present study could help inform strategic analysis of stakeholder legitimacy (e.g., Suchman, 1995; Phillips, 1997, 2003). The present study also addresses a limitation in prior 'CSR-as-insurance' studies (e.g., Godfrey, 2005; Godfrey et al., 2009; Koh et al., 2014) that have not explicitly hypothesized and/or controlled for the mediating-effect of insurance and other hedging activities on CSR spending. For example, if CSR behavior is motivated theoretically by the desire of managers, shareholders, and others to mitigate a decline in firm value (Godfrey, 2005), then logically its effectiveness in doing so will be influenced by other risk management considerations such as the amount of insurance protection in place. This study seeks to shed light on this issue.

Third, we believe that our study's research design has intrinsic advantages over many previous CSR/CSP studies. For example, our focus on the UK's non-life insurance sector inherently controls for possible biases that can arise in cross-industry and cross-country studies of CSR (e.g., as a result of different managerial motives and business risk exposures) (e.g., see Aguinis \& Glavas, 2012) ${ }^{15}$. Whereas previous 'CSR-as-insurance' studies (e.g., Godfrey et al., 2009, 2010; Koh, et al., 2014) are conducted on large and high profile exchange traded firms, our sampling frame avoids potential selection bias by including a mix of insurers of different size, financial structure, and ownership-type. Pharoah \& Walker 
(2015) argue that such an approach gives a more balanced analysis of the incidence and level of charitable giving in firms of diverse size, ownership-type and financial structure. Another novel contribution is that by incorporating financial expertise as a moderator in our analysis we allow for the effect of professional norms and obligations in ensuring effective stakeholder management. This is a managerial incentives aspect of our study that Laplume et al. (2008) argue could be important in advancing stakeholder theory-based empirical research. Our panel data design also accounts for temporal changes in both the decision to donate to charitable causes, and the amount of giving - a control-feature that is often missing in prior research (Brammer \& Millington, 2008).

Furthermore, we consider that our research moves the CSR literature forward in at least four key regards. First, our research highlights that (re)insurance (and risk hedging more generally) is a more important strategic risk management tool than CSR in protecting corporate reputation/brand from shock events. For example, CSR investment per se does not effectively protect the full portfolio of constituency interests against the costs/risks of financial distress and/or bankruptcy; but indemnification via (re)insurance does. Second, the present study suggests that strategic risk management can be likened to an 'optimization solution' that involves trade-offs between different policy options. In larger insurers, for example, this can involve evaluating the relative costs and benefits of CSR activities against more conventional risk management mechanisms. In contrast, in smaller insurers CSR investment is likely to be disconnected from the strategic risk management process as it does not serve the socio-economic and political interests of stakeholders. Third, we suggest that future 'CSR-as-insurance' research controls for the mediating-effects of other risk management activities of firms in order to improve the robustness of derived conclusions as to the risk management effectiveness of strategic CSR investment. Corporate risk hedging data could be gleaned from published sources (e.g., annual reports) and/or by using direct survey methods. Fourth, as noted in recent CSR research (e.g., El Akremi et al., 2016) future 'CSR-as-insurance' studies could use direct survey methods to examine perceptions and trade-offs at the director micro-level director regarding the motivations behind risk management (insurance) and CSR-type strategic decisions. Such studies could usefully contribute to the organizational psychology literature on risk management and risk behavior in firms operating in different sectors and institutional settings.

We acknowledge that the present study has some inherent limitations such as its focus on a narrow measure of CSR - direct charitable and altruistic community donations - and shortcomings with regard to the availability of data (e.g., the use of dummy variables). What 
is more, the robustness of our conclusions with regard to female directors may be biased by their generally low presence on the boards of UK non-life insurers during our period of analysis. On the other hand, our research design has attributes. For example, the use of charitable donations is a common and direct measure of CSR activity. Additionally, we use 12 years panel of data drawn from a representative sample of UK non-life insurers that helps account for changes in corporate giving over time. Our focus on a single country/single industry is also advantageous given that such an application mitigates potentially confounding cross-industry/trans-national effects (e.g., due to regulatory and fiscal variations) and that reinsurance and corporate donations data are readily available in the public domain. Finally, the results of our research could stimulate further empirical studies on the strategic 'insurance' function of CSR engagement in international insurance, and indeed, other industrial sectors. 


\section{REFERENCES}

Abdul Kader, H. Adams, M.B. \& Mouratidis, K. 2010). Testing for trade-offs in the reinsurance decision of U.K. life insurance firms. Journal of Accounting, Auditing and Finance, 25:491-522.

Adams, M. \& Hardwick, P. 1998. An analysis of corporate donations: United Kingdom evidence. Journal of Management Studies, 35:641-654.

Adams, R.B. \& Ferreira, D. 2009. Women in the boardroom and their impact on governance and performance. Journal of Financial Economics, 94:291-309.

Agle, B.R., Mitchell, R.K. \& Sonnenfield, J.A. 1999. Who matters to CEOs? An investigation of stakeholder attributes and salience, corporate performance, and CEO values. Academy of Management Journal, 47:507-525.

Aguinis, H. \& Glavas, A. 2012. What we know and don't know about corporate social responsibility: A review and research agenda. Journal of Management, 38:932-968.

Association of Chartered Certified Accountants (ACCA). 2011. CSR report 2010/11. London: ACCA.

Atkins, D., Fitzsimmons, A., Parsons, C. \& Punter, A. 2011. Roads to ruin. A study of major risk events: Their origins, impact and implications. London: Association of Insurance and Risk Managers in Industry and Commerce (AIRMIC).

Baker, T. 2000. Insuring morality. Economy and Society, 29:559-577.

Barnett, M.L. \& Salomon, R.M. 2012. Does it pay to be really good? Addressing the shape of the relationship between social and financial performance. Strategic Management Journal, $33: 1304-1320$.

Bhambri, A. \& Sonnenfeld, J.1988. Organization structure and corporate social performance: A field study in two contrasting industries. Academy of Management Journal, 31:642-662.

Boubakri, N., Dionne, G. \& Triki, T. 2008. Consolidation and value creation in the insurance industry: The role of governance. Journal of Banking and Finance, 32:56-88.

Brammer, S. \& Millington, A. 2003. The effect of stakeholder preferences, organizational structure and industry type on corporate community involvement. Journal of Business Ethics, $45: 213-226$.

Brammer, S. \& Millington, A.2004. The development of corporate charitable contributions in the UK: A stakeholder analysis. Journal of Management studies, 41:1411-1434.

Brammer, S. \& Millington, A. 2008. Does it pay to be different? An analysis of the relationship between corporate social and financial performance. Strategic Management Journal, 29:1325-1343. 
Brammer, S., Millington, A. \& Pavelin, S. 2009. Corporate reputation and women on the board. British Journal of Management, 20:17-29.

Brammer, S. \& Pavelin, S. 2006. Corporate reputation and social performance: The importance of fit. Journal of Management Studies, 43:435-455.

Brickley, J.A. \& Zimmerman, J.L. 2010. Corporate governance myths: Comments on Armstrong, Guay \& Weber. Journal of Accounting and Economics, 50:235-245.

Brown, W.O., Helland, E.\& Smith, J.K. 2006. Corporate philanthropic practices. Journal of Corporate Finance, 12:855-877.

Cadbury, A. 1992. Report of the committee on the financial aspects of corporate governance London: Gee Publishing.

Carroll, A.B. 1979. A three-dimensional conceptual model of corporate performance. Academy of Management Review 4: 497-505.

Chiu, S-C. \& Sharfman, M. 2011. Legitimacy, visibility, and the antecedents of corporate social performance: An investigation of the instrumental perspective. Journal of Management, 37:1558-1585.

Coffey, B.S. \& Wang, J. 1998. Board diversity and managerial control as predictors of corporate social performance. Journal of Business Ethics, 17:1595-1603.

Cole, C.R., He., E., McCullough, K.A., Semykina, A. \& Sommer, D.W. 2011. An empirical examination of stakeholder groups as monitoring sources in corporate governance. Journal of Risk and Insurance, 78:703-730.

Coombs, J.E. \& Gilley, M. 2005. Stakeholder management as a predictor of CEO compensation: Main effects and interactions with financial performance. Strategic Management Journal, 26:827-840.

den Hond, F., Rehbein, K.A., de Bakker, F.G.A. \& Lankveld, H.K. 2014. Playing on two chessboards: Reputation effects between corporate social responsibility (CSR) and corporate political activity (CPA). Journal of Management Studies, 51:79-813.

Dewing, I.P. \& Russell, P.O. 2008. The individualization of corporate governance: The approved persons' regime for UK financial services firms, Accounting, Auditing and Accountability Journal, 21: 978-1000.

El Akremi, Gond, J-P., Swaen, V., De Roeck, K. \& Igalens, J. 2016. How do employees perceive corporate responsibility? Development and validation of a multidimensional corporate stakeholder responsibility scale. Journal of Management, 42, in press.

Entine, J. 2003. The myth of social investing. Organization \& Environment, 16:352-368.

Freeman, E. 1984, A stakeholder approach, Marshfield, MA: Pitman. 
Froot, K.A. \& O'Connell, P.G.J.2008. On the pricing of intermediated risks: Theory and application to catastrophe reinsurance. Journal of Banking and Finance, 32:69-85.

Gaa J.C. \& Krinsky, I. 1988. The demand for regulation of financial disclosures: The case of the insurance industry. Journal of Business Ethics, 7: 29-39.

Godfrey, P.C. 2005. The relationship between corporate philanthropy and shareholder wealth: A risk management perspective. Academy of Management Review, 30:777-798.

Godfrey, P.C., Merrill, C.B. \& Hansen, J.M. 2009. The relationship between corporate social responsibility and shareholder value: An empirical test of the risk management hypothesis. Strategic Management Journal, 30:425-445.

Godfrey, P.C., Hatch, N.W. \& Hansen, J.M. 2010. Toward a general theory of CSRs. The roles of beneficence, profitability, insurance, and industry heterogeneity. Business and Society, 49:316-344.

Greene, W.H. 2003. Econometric analysis. New York: McGraw-Hill.

Hambrick, D.C., Werder, A.V. \& Zajac, E.J. 2008. New directions in corporate governance research. Organization Science, 19:381-385.

Hardwick, P., Adams, M. \& Zou, H. 2011. Board characteristics and profit efficiency in the United Kingdom life insurance industry. Journal of Business Finance and Accounting, 38: 987-1015.

Harjoto, M. A. \& Jo, H.2011. Corporate governance and CSR nexus. Journal of Business Ethics, 100:45-67.

Hausman, J.A. 1978. Specification tests in Econometrics. Econometrica, 46:1251-1271.

Heckman, J. 1979. Sample selection bias as a specification error. Econometrica, 47:153-161.

Heckman, J. 1981. Statistical models for discrete panel data, in Manski, C. and McFadden, D. (eds.), The structural analysis of discrete data. Cambridge, MA: MIT Press.

Hoetker, G. 2007. The use of logit and probit models in strategic management research: Critical issues. Strategic Management Journal, 28:331-343.

Hsu, K-T. 2012. The advertising effects of corporate social responsibility on corporate reputation and brand equity: Evidence from the life insurance industry in Taiwan. Journal of Business Ethics, 109:189-201.

Ibrahim, N.A., Howard, D.P. \& Angelidis, J.P. 2003. Board members in the service industry: An empirical examination of the relationship between corporate social responsibility orientation and directorial type. Journal of Business Ethics, 47:393-401.

International Underwriting Association (IUA) 2013. London company market statistics report 2013. IUA: London. 
Jaccard, J., Turrisi, R. \& Wan, C.K. 1990. Interaction effects in multiple regression, Sage University Paper Series on Quantitative Applications in the Social Sciences, 07-069. Newbury Park, CA: Sage Publications.

Jensen, M.C. 2002. Value maximization, stakeholder theory, and the corporate objective function. Business Ethics Quarterly, 12:235-256.

Jia, N. 2013. Competition, governance, and relationship-specific investments: Theory and implications for strategy. Strategic Management Journal, 34:1551-1567.

Jia, N. 2014. Are collective political actions and private political actions substitutes or complements? Empirical evidence from China's private sector. Strategic Management Journal, 35:292-315.

Jo, H. \& Harjoto, M. A. 2011. Corporate governance and firm value: The impact of corporate social responsibility. Journal of Business Ethics, 103:351-383.

Jo, H. \& Na, H. 2012. Does CSR reduce firm risk? Evidence from controversial industry sectors. Journal of Business Ethics, 110:441-456.

Kaler, J. 2003. Differentiating stakeholder theories. Journal of Business Ethics, 46:71-83.

Kaler, J. 2006. Evaluating stakeholder theory. Journal of Business Ethics, 69:249-268.

Kennedy, P. 2003. A guide to econometrics. Oxford: Blackwell.

Koehn, D. \& Ueng, J. 2010. Is philanthropy being used by corporate wrongdoers to buy goodwill? Journal of Management and Governance, 14:1-16.

Koh, P-S, Qian, C. \& Wang, H. 2014. Firm litigation risk and the insurance value of corporate social performance. Strategic Management Journal, 35: 1464-1482.

Krüger, P. 2015. Corporate goodness and shareholder wealth. Journal of Financial Economics, 115:304-329.

Kvalnes, Ø. 2011. Blurred promises: Ethical consequences of fine print policies in insurance. Journal of Business Ethics, 103:77-86.

Lan, L.L. \& Heracleous, L. 2010. Rethinking agency theory: The view from law. Academy of Management Review, 35: 294-314.

Laplume, A.O., Sonpar, K. \& Litz, R.A. 2008. Stakeholder theory: Reviewing a theory that moves us. Journal of Management, 34:1152-1189.

Li, S.X. \& Greenwood, R. 2004. The effect of within-industry diversification on firm performance: Synergy creation, multi-market contact, and market structuration. Strategic Management Journal, 25:1131-1153. 
Lin, C., Lin, P. \& Zou, H. 2012. Does property rights protection affect corporate risk management strategy? Intra- and cross-country evidence, Journal of Corporate Finance, 18: 311-330.

Lloyd's of London Insurance Market (2014), Lloyd's 2014 Annual Report. London: Lloyd's.

Mahoney, L.S. \& Thorn, L. 2006. An examination of the structure of executive compensation and corporate social responsibility. Journal of Business Ethics, 69:149-162.

Marquis, C. \& Qian, C. 2014. Corporate social responsibility reporting in China: Symbol or substance? Organization Science, 25:127-148.

Masulis, R.W. \& Reza, S.W. 2015. Agency problems of corporate philanthropy. Review of Financial Studies, 28: 592-636.

McKinsey, 2015. Charitable giving in the property and casualty insurance industry: an update. New York: McKinsey \& Company.

McWilliams, A. \& Siegel, D. 2000. Corporate social responsibility and financial performance: Correlation or misspecification? Strategic Management Journal, 21:603-609.

Moore, G. 2001. Corporate social and financial performance: An investigation in the U.K. supermarket industry. Journal of Business Ethics, 34:299-315.

Muller, A.R., Pfarrer, M.D. \& Little, L.M. 2014. A theory of collective empathy in corporate philanthropy decisions. Academy of Management Review, 39: 1-21.

Navarro, P. 1988. Why do corporations give to charity? Journal of Business, 61: 65-93.

Peloza, J. 2006. Using corporate social responsibility as insurance for financial performance. California Management Review, 48:52-72.

Pharoah, C. \& Walker, C. 2015. The values of corporate giving: An overview of models and case studies. London :Cass University Business School.

Phillips, R. 1997. Stakeholder theory and a principle of fairness. Business Ethics Quarterly, 7: 51-66.

Phillips, R. 2003. Stakeholder legitimacy. Business Ethics Quarterly, 13: 25-41.

Phillips, R., Freeman, R.E. \& Wicks, A.C. 2003. What stakeholder theory is not. Business Ethics Quarterly, 13: 479-502.

Rochet, J-C. \& Villebeuve, S. 2011. Liquidity management and corporate demand for hedging and insurance. Journal of Financial Intermediation, 20: 303-323.

Schwartz, M.S. \& Carroll, A.B. 2003. Corporate social responsibility: A three-domain approach. Business Ethics Quarterly, 13: 503-530.

Suchman, M.C. 1995. Managing legitimacy: Strategic and institutional approaches. Academy of Management Review, 20: 571-610. 
UK Companies Act 1985. London: HMSO.

UK Companies Act 2006. London: HMSO.

UK Financial Services and Markets Act 2000. London:.HMSO.

Upreti, V. \& Adams, M. 2015. The strategic role of reinsurance in the United Kingdom's (UK) non-life insurance market. Journal of Banking and Finance, 61:206-219.

Walls, J.L., Berrone, P. \& Phan, P.H. 2012. Corporate governance and environmental performance: Is there really a link? Strategic Management Journal, 33:885-913.

Webb, D. \& Pettigrew, A. 1999. The temporal development of strategy: Patterns in the U.K. insurance industry. Organization Science, 10:601-621.

WestLB AG (2004), Insurance and sustainability: Playing with fire, London: WestLB AG.

Wu, M-W. \& Shen, C-H. 2013. Corporate social responsibility in the banking industry: Motives and financial performance. Journal of Banking and Finance, 37:3529-3547.

Zimmeck, M. \& Pharoah, C. 2015. The Values of corporate giving: An update on key figures and trends. London: Cass Business School.

Zou, H. \& Adams, M. B. 2008. Debt capacity, cost of debt, and corporate insurance. Journal of Financial and Quantitative Analysis, 43:433-466. 


\title{
NOTES
}

\begin{abstract}
${ }^{1}$ In 2012/13 there were 976 non-life insurance entities licensed to operate in the UK but only about a third of these entities actively underwrite insurance business. Non-active insurance operatives include a miscellany of structures such as closed funds in run-off, 'brass plate' branches of overseas firms, and protection and indemnity pools that do not underwrite third party risks.
\end{abstract}

${ }^{2}$ Koehn \& Ueng (2010) report that philanthropy can be a 'window-dressing' exercise aimed at distracting public media attention away from activities that generate negative externalities on economy and society (e.g., environmental pollution). Whilst insurers do not create obvious negative externalities in the same way as say a mining company, their business activities can nonetheless have negative socio-economic effects. For example, as Baker (2000) reports, discriminatory risk pricing/selection can exclude certain social groups (e.g., the poor) from insurance markets. However, the implicit altruistic assumption in our paper holds in insurance because as we have noted earlier, insurance is fundamentally a 'trust and relationship' business and that non-altruistic activities risk being exposed in the public domain with a potentially deleterious impact on an insurer's public reputation for 'prudence and fair dealing'.

${ }^{3}$ A case in point here is Admiral plc which entered the highly competitive UK motor insurance market in 1993 and became the subject of a board-level management buyout in the late 1990s with the assistance of a $75 \%$ reinsurance agreement with a syndicate of external reinsurers the most notable being Munich Re. Indeed, from its earliest days a representative of Munich Re has sat on the board of Admiral plc. Over the period of analysis, Admiral plc was a consistent and above market average cash contributor to charitable causes (e.g., with direct cash donations of $£ 141,000$ in 2012). Admiral plc's share of the UK motor insurance market in annual premium terms is around $12 \%$, and it is currently the second largest UK motor insurer in terms of the total number of vehicles insured.

${ }^{4}$ The panel sample of 77 insurance firms arises after trimming for incomplete data. We consider that our use of a balanced panel does not raise concerns about survivorship bias as average levels of charitable donations were generally low (i.e., about $£ 50,000$ per annum per Table 2). As such, philanthropy, and CSR activity more generally, are unlikely to be contributory factors behind market exits (e.g., due to insolvency and/or takeover activity). Also, there were very few new entrants to the UK's non-life insurance market during our period of analysis (1999 to 2010). A balanced panel design also has the advantage of allowing us to examine charitable giving for each insurance firm in every time period examined thus promoting consistency of analysis and minimizing 'noise' arising from firm-level heterogeneity (Greene, 2003).

${ }^{5}$ From 1 April 2013 the statutory supervision and regulation of UK insurance companies is conducted by the new Prudential Regulation Authority (PRA), whilst matters of insurance market operation are regulated by the Financial Conduct Authority (FCA). The PRA is part of the Bank of England and the FCA is an independent regulatory body which is accountable to HM Treasury.

${ }^{6}$ At the beginning of our data period the UK non-life insurance industry experienced some corporate governance failures notably the demise of Independent Insurance plc in 2001 (Atkins, Fitzsimmons, Parsons, \& Punter, 2011). As noted earlier, the 2007/8 global financial crisis and the demise of AIG further raised the profile of CSR on the strategic agenda of insurance companies both in the UK and internationally (WestLB AG, 2004). However, we note that the 20078 global financial crisis had no discernible effect on the corporate decision to donate to charitable causes (or indeed the purchase of reinsurance). Our observation accords with Wu \& Shen (2013) who find consistency in CSR activity among international banks in the years immediately before and during the 2007/8 global financial crisis.

${ }^{7}$ The beneficiaries of UK insurers' charitable contributions over our period of analysis (1999 to 2010) are many and varied, and included registered national and international charities as well as local community groups. However, the amount donated to particular charitable causes is not always disclosed thereby precluding a 'fine' analysis of the purpose of charitable giving.

${ }^{8}$ The UK's Companies Act (2006, sections 382/465) currently makes it a statutory requirement for companies (except small companies with annual turnover below $£ 6.5$ million and total assets of $£ 3.26$ million) to disclose annual charitable donations over $£ 2,000$. However, the small companies' exemption does not apply to insurance firms under the Financial Markets Services Act (FSMA) (2000).As publicly reported accounting items, corporate donations in the UK are subject to external audit certification - a situation that does not exist in many other countries, including the United States (US) where charitable contributions are not required to be disclosed 
in companies' published annual accounting statements (e.g., see Masulis \& Reza, 2015). Statutory disclosure requirements for charitable donations in the UK go back further than 2006 to section 234(3) and Schedule 7 (paragraphs 3 and 4) of the 1985 Companies Act (Adams and Hardwick, 1998). Also, prior to 2006 it was established 'good practice' (e.g., as advocated by professional accountancy bodies) for UK companies to disclose contributions to charitable causes in the annual report and accounts. Therefore, missing data due to unreported contributions to charitable causes is unlikely to be problematical in the current UK-based study. Additionally, compared with charitable giving, payments to political parties are rare in the UK corporate sector (Brammer \&Millington, 2003).

${ }^{9} \mathrm{McWilliams} \&$ Siegel (2000) report that research and development (R\&D) and advertising and promotion (A\&P) expenditures should be controlled for in CSR research. However, R\&D and A\&P expenditures were not identifiable from our sources of data. In any case, it is likely that such expenditures are, at least to some extent, captured by other control variables such as firm size, profitability, and age.

${ }^{10} \mathrm{We}$ assume that there is a conjoint theoretical linkage between the 'participation' and 'volume' decision. For example, all else equal, a large publicly visible insurer is likely to have the resources necessary not only to donate but give more generously than a smaller insurer with a less prominent public profile. However, we acknowledge that this assumption may not always hold true in practice. For example, a big insurer may be willing to donate to charities but may be financially constrained to donate large sums to charitable causes.

${ }^{11}$ As a further precaution against potential endogeneity, we followed Masulis \& Reza (2015) and estimated our regressions using single period lags whereby the independent variables in period $t$ were regressed against the charitable donations indicators in period ${ }_{t+1}$. This had the effect of reducing the total number of firm/year observations from 924 to 847 . The results are qualitatively unchanged

${ }^{12}$ VIFs are computed as $1\left(1-\mathrm{R}^{2}\right)$, where $\mathrm{R}^{2}$ is derived from regressing individual explanatory variables on all other explanatory variables (Kennedy, 2003). To further mitigate the risk of multicollinearity and so improve the robustness of our results we mean-centered the variables of interest in conducting the multivariate analyses (see also note 16).

${ }^{13}$ Another reason for excluding BSIZE from the regression analysis is that this variable could be simultaneously determined with other board composition variables such as the proportion of outside board members.

${ }^{14}$ Multicollinearity can arise between each interaction term (e.g., REINS x OUTS) and its constituent parts (e.g., REINS and OUTS). To resolve this issue we use the 'centering' transformation procedure of Jaccard, Turrisi \& Wan (1990), which involves 'centering' corresponding continuous variables by subtracting sample means before constructing the interaction term. The centered forms of the corresponding constituent variables are then used in the probit and tobit estimations to reduce correlations between the multiplicative term and the component variables.

${ }^{15}$ Aside from possible biases (e.g., different regulatory and fiscal rules) in cross-sectional/trans-national studies the main reason for focusing on cash charitable donations in the UK non-life insurance industry is data availability. Li \& Greenwood (2004) also note that intra-industry studies have advantages for management research - for example, as 'natural control environments' unimpeded by different institutional-effects. 
Table 1: UK Non-Life Insurers 1999-2010: Definition of Variables

\begin{tabular}{|c|c|c|c|c|}
\hline \multicolumn{2}{|c|}{ VARIABLE } & \multirow{2}{*}{$\begin{array}{r}\text { REPRESENTS } \\
\text { Corporate } \\
\text { Donations }\end{array}$} & \multirow{2}{*}{$\begin{array}{c}\text { DEFINITION } \\
\text { Annual corporate donations }\end{array}$} & \multirow[t]{2}{*}{ PREDICTION } \\
\hline $\begin{array}{l}\text { Dependent } \\
\text { variable }\end{array}$ & $D O N_{i t}$ & & & \\
\hline & $D D U M_{i t}$ & $\begin{array}{l}\text { Corporate } \\
\text { Donations }\end{array}$ & $\begin{array}{l}\text { Binary variable equal to } 1 \text { if } \\
\text { an insurer has donated in } \\
\text { time } t \text {, and } 0 \text { otherwise. }\end{array}$ & \\
\hline $\begin{array}{c}\text { Main } \\
\text { independent } \\
\text { variable }\end{array}$ & REINS $_{i t}$ & $\begin{array}{l}\text { Annual } \\
\text { reinsurance } \\
\text { purchases }\end{array}$ & $\begin{array}{l}\text { Annual premiums ceded to } \\
\text { reinsurers / annual gross } \\
\text { premiums written (including } \\
\text { reinsurance assumed) }\end{array}$ & $+/-$ \\
\hline \multirow[t]{7}{*}{$\begin{array}{l}\text { Corporate } \\
\text { governance } \\
\text { variables }\end{array}$} & $B S I Z E_{i t}$ & Board Size & Number of board members & + \\
\hline & OUTS $_{i t}$ & $\begin{array}{l}\text { Outside (non- } \\
\text { executive) } \\
\text { directors }\end{array}$ & $\begin{array}{l}\text { Percentage of outside } \\
\text { directors to total board } \\
\text { members }\end{array}$ & + \\
\hline & $S E P_{i t}$ & $\begin{array}{l}\text { Separation of the } \\
\text { CEO and } \\
\text { Chairman position }\end{array}$ & $\begin{array}{c}\text { A binary variable of } 1 \text { if the } \\
\text { CEO and Chairman } \\
\text { functions are separate, and } 0 \\
\text { otherwise }\end{array}$ & + \\
\hline & $I N S I D E_{i t}$ & Insider ownership & $\begin{array}{l}\text { Binary variable equal to } 1 \text { if } \\
\text { an insurer has a managerial } \\
\text { share ownership scheme, } \\
\text { and } 0 \text { otherwise }\end{array}$ & + \\
\hline & $C O M P_{i t}$ & $\begin{array}{l}\text { CEO incentive } \\
\text { compensation }\end{array}$ & $\begin{array}{l}\text { A binary variable of } 1 \text { if the } \\
\text { CEO receives incentive } \\
\text { compensation (e.g. bonus or } \\
\text { stock options), and } 0 \\
\text { otherwise }\end{array}$ & + \\
\hline & $G-M I X_{i t}$ & Gender mix & $\begin{array}{l}\text { Percentage of female } \\
\text { directors to total board } \\
\text { members }\end{array}$ & + \\
\hline & $P_{R O F_{i t}}$ & $\begin{array}{l}\text { Finance } \\
\text { professional } \\
\text { representation }\end{array}$ & $\begin{array}{c}\text { Percentage of qualified } \\
\text { finance professionals to total } \\
\text { board members }\end{array}$ & + \\
\hline \multirow[t]{2}{*}{$\begin{array}{c}\text { Firm-specific } \\
\text { control } \\
\text { variables }\end{array}$} & $S I Z E_{i t}$ & Firm size & $\begin{array}{l}\text { Total value of assets } \\
\text { (inflation-adjusted) }\end{array}$ & + \\
\hline & $O W N_{i t}$ & $\begin{array}{l}\text { Ownership } \\
\text { structure }\end{array}$ & $\begin{array}{l}\text { Percentage of shares held by } \\
\text { the top- } 3 \text { shareholders to }\end{array}$ & - \\
\hline
\end{tabular}


Reinsurance and Charitable Giving in Insurance

\begin{tabular}{|l|c|c|c|c|}
\hline & PROFIT $i t$ & Profitability & total shares in issue. & $\begin{array}{c}\text { Annual earnings before } \\
\text { interest \& taxes (millions) } \\
\text { (inflation-adjusted) }\end{array}$ \\
\hline & $L E V_{i t}$ & Leverage & $\begin{array}{c}\text { Percentage of annual } \\
\text { premiums written to total } \\
\text { capital (equity + reserves) } \\
\text { i.e., the premium-to-surplus } \\
\text { (P-S) ratio }\end{array}$ & + \\
\hline & $P-L I N E_{i t}$ & Product-Mix & $\begin{array}{c}\text { A binary variable equal to 1 } \\
\text { for multiple lines insurers, } \\
\text { and 0 otherwise }\end{array}$ & + \\
\hline & $A G E_{i t}$ & $\begin{array}{c}\text { Length of time an } \\
\text { insurer has been } \\
\text { operating }\end{array}$ & Number of years of \\
operation. & \\
\hline & & & + \\
\hline
\end{tabular}

Note: Dummy variables are used where metric data were not available from public sources. 
Table 2: UK Insurers 1999-2010: Descriptive statistics of explanatory variables

\begin{tabular}{lccccc}
$\begin{array}{l}\text { Panel A: Pooled (1999-2010) } \\
\text { Variable }\end{array}$ & Mean & Median & $\begin{array}{c}\text { Std. } \\
\text { Dev. }\end{array}$ & Min & Max \\
\hline DON & 0.05 & 0.00 & 2.15 & 0.00 & $2 . .60$ \\
REINS & 0.34 & 0.31 & 1.14 & 0.05 & 3.05 \\
BSIZE & 7.00 & 6.00 & 3.00 & 3.00 & 16.00 \\
OUTS & 0.55 & 0.55 & 0.12 & 0.00 & 0.82 \\
SEP & 0.92 & 1.00 & 0.27 & 0.00 & 1.00 \\
INSIDE & 0.38 & 0.00 & 0.49 & 0.00 & 1.00 \\
COMP & 0.84 & 1.00 & 0.36 & 0.00 & 1.00 \\
G-MIX & 0.03 & 0.00 & 0.07 & 0.00 & 0.40 \\
PROF & 0.28 & 0.25 & 0.11 & 0.00 & 0.88 \\
SIZE & 997 & 54 & 3,727 & 1.8 & 31,220 \\
OWN & 0.63 & 0.67 & 0.29 & 0.00 & 1.00 \\
PROFIT & 50.45 & 2.78 & 255 & -237 & 2,977 \\
LEV & 1.18 & 1.11 & 0.25 & 0.53 & 3.85 \\
P-LINE & 0.03 & 0.00 & 0.16 & 0.00 & 1.00 \\
AGE & 48.40 & 34.00 & 33.83 & 2.00 & 133 \\
\hline
\end{tabular}

Panel B: Donators (1999-

2010)

Variable

DON

REINS

BSIZE

OUTS

SEP

INSIDE

COMP

$G-M I X$

PROF

SIZE

OWN

PROFIT

LEV

P-LINE

$A G E$
Std.

$\begin{array}{ccccc}\text { Mean } & \text { Median } & \text { Dev. } & \text { Min } & \text { Max } \\ 0.11 & 0.08 & 0.21 & 0.01 & 1.60\end{array}$

$\begin{array}{lllll}0.29 & 0.30 & 0.07 & 0.05 & 0.65\end{array}$

$\begin{array}{lllll}7.80 & 8.00 & 2.64 & 4.00 & 16.00\end{array}$

$\begin{array}{lllll}0.59 & 0.60 & 0.11 & 0.20 & 0.82\end{array}$

$\begin{array}{lllll}0.94 & 1.00 & 0.23 & 0.00 & 1.00\end{array}$

$\begin{array}{lllll}0.54 & 1.00 & 0.50 & 0.00 & 1.00\end{array}$

$\begin{array}{lllll}0.77 & 1.00 & 0.50 & 0.00 & 1.00\end{array}$

$\begin{array}{lllll}0.04 & 0.00 & 0.07 & 0.00 & 0.25\end{array}$

$\begin{array}{lllll}0.30 & 0.27 & 0.12 & 0.11 & 0.88\end{array}$

$\begin{array}{lllll}2,043 & 109 & 5,291 & 2.00 & 31,220\end{array}$

$\begin{array}{lllll}0.56 & 0.67 & 0.33 & 0.00 & 1.00\end{array}$

$\begin{array}{lllll}103 & 15.00 & 369 & -237 & 2,977\end{array}$

$\begin{array}{lllll}1.25 & 1.16 & 0.25 & 0.64 & 2.83\end{array}$

$\begin{array}{lllll}0.06 & 0.00 & 0.23 & 0.00 & 1.00\end{array}$

$\begin{array}{lllll}55.56 & 39.00 & 36.57 & 2.00 & 133\end{array}$




\begin{tabular}{lccccc}
$\begin{array}{l}\text { Panel C: Non-donators } \\
\text { (1999-2010) } \\
\text { Variable }\end{array}$ & Mean & Median & $\begin{array}{c}\text { Std. } \\
\text { Dev. }\end{array}$ & Min & Max \\
\hline DON & 0.00 & 0.00 & 0.00 & 0.00 & 0.00 \\
REINS & 0.38 & 0.31 & 1.56 & 0.05 & 3.05 \\
BSIZE & 5.42 & 5.00 & 1.74 & 3.00 & 12.00 \\
OUTS & 0.52 & 0.50 & 0.12 & 0.00 & 0.75 \\
SEP & 0.90 & 1.00 & 0.30 & 0.00 & 1.00 \\
INSIDE & 0.24 & 0.00 & 0.43 & 0.00 & 1.00 \\
COMP & 0.91 & 1.00 & 0.29 & 0.00 & 1.00 \\
G-MIX & 0.01 & 0.00 & 0.06 & 0.00 & 0.40 \\
PROF & 0.27 & 0.25 & 0.10 & 0.00 & 0.67 \\
SIZE & 99 & 35 & 234 & 10 & 2,198 \\
OWN & 0.70 & 0.70 & 0.23 & 0.30 & 1.00 \\
PROFIT & 4.92 & 1.89 & 15.97 & -50 & 178 \\
LEV & 1.11 & 1.08 & 0.23 & 0.53 & 3.85 \\
P-LINE & 0.00 & 0.00 & 0.00 & 0.00 & 0.00 \\
AGE & 42.25 & 31.00 & 29.97 & 3.00 & 128 \\
\hline & & & & & \\
\hline
\end{tabular}

\begin{tabular}{|c|c|c|c|}
\hline $\begin{array}{l}\text { Panel D: Donators v. Non- } \\
\text { Donators }\end{array}$ & $\begin{array}{l}\text { Don. } \\
\text { Mean }\end{array}$ & $\begin{array}{c}\text { Non- } \\
\text { Donators } \\
\text { Mean }\end{array}$ & $\begin{array}{c}\text { t- } \\
\text { /WMWU/X } \\
\text { statistics }\end{array}$ \\
\hline REINS & 0.29 & 0.38 & $2.442 *$ \\
\hline BSIZE & 8 & 5 & $16.32^{* *}$ \\
\hline OUTS & 0.59 & 0.52 & $-8.82 * *$ \\
\hline$S E P$ & 0.94 & 0.90 & $5.21 *$ \\
\hline INSIDE & 0.54 & 0.24 & $87.48^{* *}$ \\
\hline СOMP & 0.77 & 0.91 & $30.70^{* *}$ \\
\hline$G-M I X$ & 0.04 & 0.01 & $-6.21 * *$ \\
\hline PROF & 0.30 & 0.27 & $-4.60 * *$ \\
\hline$R(S I Z E)$ & .64 & .38 & $-15.83^{* *}$ \\
\hline OWN & 1.25 & 1.10 & $9.12 * *$ \\
\hline$R(P R O F I T)$ & .62 & .40 & $-12.95^{* *}$ \\
\hline$L E V$ & 1.25 & 1.11 & $-9.12 * *$ \\
\hline P-LINE & 0.06 & 0.00 & $28.68^{* *}$ \\
\hline$R(A G E)$ & .48 & .52 & $2.45^{* *}$ \\
\hline
\end{tabular}


Note: This table gives the summary statistics for the panel of UK insurers in our sample (924 firm/year cases) plus separatehe summary statistics for donating (554 firm/year cases) and non-donating insurance firms (370 firm/year cases). Continuous variables are measured in $f$ millions. We replace SIZE, PROFIT and $A G E$ with their rank-transformed equivalents $R(S I Z E), R(P R O F I T)$ and $R(A G E)$ to address the effects of extreme values. Thirty-five insurers did not donate in any year of analysis; four insurance firms gave in some years but not others and 48 firms were consistent in terms of donations (but not necessarily the amount donated) over the period of analysis. Ten (mainly small) firms in the data set were mutual forms of organization. The low percentage $(13 \%)$ of mutual insurers in the sample precluded the need to test for organizational form-effects on the charitable donation decision. Definitions of the variables are given in Table 1. The Wilcoxon-MannWhitney $\mathrm{U}$ test is used for REINS (as REINS has a skewed distribution) and t-test for all other continuous variables. $\mathrm{X}^{2}$ test is used to test the independence between categorical variables (SEP, INSIDE, and COMP) and the incidence of donation. In panel $\mathrm{B}$ the statistical significance values *** denote statistical significance at the $5 \%$ and $1 \%$ levels, respectively (two-tail). 
Reinsurance and Charitable Giving in Insurance

\section{Table 3: UK Insurers 1999-2010: Correlation coefficient matrix}

\begin{tabular}{|c|c|c|c|c|c|c|c|c|c|c|c|c|c|c|c|c|c|c|c|c|c|}
\hline VARIABLES & 1 & 2 & 3 & 4 & 5 & 6 & 7 & 8 & 9 & 10 & 11 & 12 & 13 & 14 & 15 & 16 & 17 & 18 & 19 & 20 & 21 \\
\hline$D O N$ & 1.00 & & & & & & & & & & & & & & & & & & & & \\
\hline$D D U M$ & $0.94 * *$ & 1.00 & & & & & & & & & & & & & & & & & & & \\
\hline REINS & $-0.28 *$ & $-0.39 * *$ & 1.00 & & & & & & & & & & & & & & & & & & \\
\hline..$B S I Z E$ & $0.55^{* *}$ & $0.48 * *$ & -0.23 & 1.00 & & & & & & & & & & & & & & & & & \\
\hline OUTS & $0.31 * *$ & $0.29 *$ & -0.04 & $0.44 * *$ & 1.00 & & & & & & & & & & & & & & & & \\
\hline$S E P$ & 0.07 & 0.07 & 0.05 & -0.03 & 0.12 & 1.00 & & & & & & & & & & & & & & & \\
\hline I NSIDE & $0.36^{* *}$ & $0.31^{*}$ & $-0.42 * *$ & $0.34 * *$ & 0.04 & -0.07 & 1.00 & & & & & & & & & & & & & & \\
\hline$C O M P$ & -0.17 & $-0.18^{*}$ & -0.18 & -0.07 & -0.04 & 0.27 & 0.18 & 1.00 & & & & & & & & & & & & & \\
\hline$G-M I X$ & $0.38^{* *}$ & $0.32 *$ & 0.02 & $0.41 * *$ & $0.23 *$ & 0.04 & 0.09 & 0.03 & 1.00 & & & & & & & & & & & & \\
\hline $0 . P R O F$ & 0.16 & 0.16 & 0.00 & 0.21 & 0.09 & 0.04 & 0.10 & -0.18 & 0.13 & 1.00 & & & & & & & & & & & \\
\hline 1..R(SIZE) & $0.52 * *$ & $0.46^{* *}$ & -0.14 & $0.66 * *$ & $0.27 *$ & -0.07 & 0.22 & -0.11 & $0.42 *$ & 0.21 & 1.00 & & & & & & & & & & \\
\hline $2 . O W N$ & $-0.24 *$ & $-0.24 *$ & 0.09 & -0.13 & -0.20 & $-0.36^{* *}$ & 0.23 & 0.09 & -0.05 & 0.06 & -0.10 & 1.00 & & & & & & & & & \\
\hline 3.R(PROFIT) & $0.43 * *$ & $0.39 * *$ & -0.23 & $0.51 * *$ & 0.21 & 0.08 & $0.27^{*}$ & -0.14 & $0.34 *$ & 0.08 & $0.67 * *$ & -0.08 & 1.00 & & & & & & & & \\
\hline 4.LEV & $-0.45^{* *}$ & $-0.44 * *$ & $-0.28 *$ & $0.41 * *$ & 0.19 & 0.18 & $0.30 *$ & 0.10 & $0.29 *$ & 0.08 & $0.44 *$ & 0.04 & $0.53 * *$ & 1.00 & & & & & & & \\
\hline 5.P-LINE & 0.10 & 0.11 & 0.09 & 0.08 & 0.08 & 0.01 & 0.04 & 0.11 & 0.10 & 0.12 & 0.13 & 0.11 & $0.20^{*}$ & $0.22 *$ & 1.00 & & & & & & \\
\hline $6 . R(A G E)$ & $0.28 *$ & 0.08 & 0.10 & $0.33^{*}$ & -0.04 & 0.05 & $-0.42 *$ & -0.18 & $0.20 *$ & 0.00 & -0.14 & 0.09 & $-0.23 *$ & $-0.25^{*}$ & 0.03 & 1.00 & & & & & \\
\hline 7.REINSXOUTS & 0.11 & 0.10 & $0.60 * *$ & $0.22 *$ & $0.71 *$ & 0.12 & $-0.24 *$ & $0.29 *$ & $0.23 *$ & 0.11 & 0.12 & -0.10 & 0.10 & 0.10 & 014 & $0.63 * *$ & 1.00 & & & & \\
\hline 8.REINSXSEP & 0.14 & 0.00 & $0.90 * *$ & $-0.22 *$ & $\stackrel{*}{*} .00$ & $0.53^{* *}$ & $-0.41 * *$ & 0.10 & 0.11 & 0.12 & -0.11 & $-0.22 *$ & 0.14 & $0.30 *$ & 0.11 & $0.90 * *$ & $0.61 * *$ & 1.00 & & & \\
\hline 9.REINSXINSIDE & $0.30^{*}$ & $0.33 *$ & $-0.30 *$ & $0.34 *$ & 0.00 & -0.12 & $0.90 * *$ & $0.23 *$ & 0.12 & $-0.44 * *$ & $0.31 *$ & $0.23 *$ & 0.12 & -0.13 & 0.12 & $-0.30 *$ & -0.10 & $0.32 *$ & 1.00 & & \\
\hline O.REINSXCOMP & $-0.31 *$ & $-0.24 *$ & $0.62 * *$ & $-0.24 *$ & -0.10 & $0.24 *$ & $0.34 *$ & $0.62 * *$ & 0.13 & 0.14 & 0.11 & $-0.31 *$ & 0.18 & $0.31 *$ & 0.10 & $0.62 * *$ & $0.41 * *$ & $0.63 * *$ & 0.11 & 1.00 & \\
\hline 1.REINSXG-MIX & $0.40 * *$ & $0.31^{*}$ & 0.10 & $0.42 * *$ & $0.24 *$ & 0.10 & 0.12 & 0.12 & $0.91 * *$ & 0.11 & -0.10 & $0.30 *$ & 0.17 & 0.18 & 0.14 & 0.10 & $0.24 *$ & 0.12 & 0.13 & 0.14 & 1.00 \\
\hline 2.REINSXPROF & 0.10 & 0.13 & $0.53 * *$ & 0.11 & 0.12 & 0.13 & -0.11 & $-0.31^{*}$ & $0.31 *$ & $0.81^{* *}$ & 0.12 & 0.10 & 0.12 & -0.11 & 0.11 & $0.53 * *$ & $0.42 * *$ & $0.51^{* *}$ & 0.10 & 0.14 & 0.10 \\
\hline
\end{tabular}

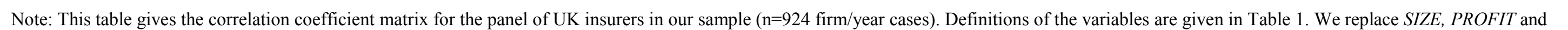

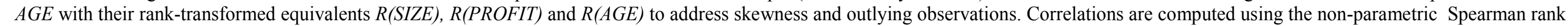
correlation test. *,**, denote statistical significance at the $5 \%$ and $1 \%$ levels respectively (two-tail). 
Reinsurance and Charitable Giving in Insurance

Table 4: UK Insurers 1999-2010: Estimates and marginal-effects of the random-effects probit model

Panel A: Random-effects probit model estimates

\begin{tabular}{|c|c|c|c|}
\hline & Model 1 & Model 2 & Model 3 \\
\hline \multirow[t]{2}{*}{$R(S I Z E)(+)$} & $5.89 * *$ & $5.90^{* *}$ & $16.65^{* *}$ \\
\hline & $(0.00)$ & $(0.00)$ & $(0.00)$ \\
\hline \multirow[t]{2}{*}{ OWN } & -1.34 & -0.82 & $-3.73 *$ \\
\hline & $(0.31)$ & $(0.55)$ & $(0.05)$ \\
\hline \multirow[t]{2}{*}{$L E V$} & -0.58 & -0.51 & -0.91 \\
\hline & $(0.50)$ & $(0.65$ & $(0.70)$ \\
\hline \multirow[t]{2}{*}{$P-L I N E$} & 13.67 & 16.15 & 10.06 \\
\hline & $(0.11)$ & $(0.97)$ & $(0.99)$ \\
\hline \multirow[t]{2}{*}{$R(P R O F I T)$} & 1.00 & -0.59 & -3.88 \\
\hline & $(0.38)$ & $(0.70)$ & $(0.18)$ \\
\hline \multirow[t]{2}{*}{$R(A G E)$} & $1.66^{*}$ & $9.39^{* *}$ & $17.96^{* *}$ \\
\hline & $(0.05)$ & $(0.00)$ & $(0.00)$ \\
\hline \multirow[t]{2}{*}{ REINS } & & $-31.58 * *$ & $-23.24 *$ \\
\hline & & $(0.01)$ & $(0.02)$ \\
\hline \multirow[t]{2}{*}{ OUTS } & & $3.78^{*}$ & $6.04 * *$ \\
\hline & & $(0.03)$ & $(0.00)$ \\
\hline \multirow[t]{2}{*}{ SEP } & & 1.46 & -27.27 \\
\hline & & $(0.16)$ & $(0.31)$ \\
\hline \multirow[t]{2}{*}{ INSIDE } & & $4.10^{* *}$ & $32.60^{*}$ \\
\hline & & $(0.00)$ & $(0.02)$ \\
\hline \multirow[t]{2}{*}{$C O M P$} & & $-3.52 * *$ & $-56.17 *$ \\
\hline & & $(0.00)$ & $(0.02)$ \\
\hline \multirow[t]{2}{*}{$G-M I X$} & & $11.80 * *$ & $17.79^{*}$ \\
\hline & & $(0.01)$ & $(0.05)$ \\
\hline \multirow[t]{2}{*}{ PROF } & & $-0.31 * *$ & $-9.29 *$ \\
\hline & & $(0.00)$ & $(0.05)$ \\
\hline \multirow[t]{2}{*}{ REINS $x$ OUTS } & & & -365.00 \\
\hline & & & $(0.23)$ \\
\hline \multirow[t]{2}{*}{ REINS $x$ SEP } & & & 106.13 \\
\hline & & & $(0.25)$ \\
\hline \multirow[t]{2}{*}{ REINS $x$ INSIDE } & & & $-49.20^{*}$ \\
\hline & & & $(0.03)$ \\
\hline \multirow[t]{2}{*}{ REINS $x$ COMP } & & & $126.42 *$ \\
\hline & & & $(0.03)$ \\
\hline \multirow[t]{2}{*}{ REINS $x$ G-MIX } & & & $-576.71 *$ \\
\hline & & & $(0.05)$ \\
\hline \multirow[t]{2}{*}{ REINS $\times$ PROF } & & & 75.85 \\
\hline & & & $(0.86)$ \\
\hline \multirow[t]{2}{*}{ CONSTANT } & $-4.51 * *$ & 0.71 & $57.96^{*}$ \\
\hline & $(0.00)$ & $(0.84)$ & $(0.03)$ \\
\hline Estimated $\mathrm{p}$ & 0.91 & 0.96 & 0.99 \\
\hline \multicolumn{4}{|c|}{ Likelihood-ratio test of $p=0$ : } \\
\hline$X^{2}(01)$ & 742 & 627 & 571 \\
\hline
\end{tabular}


Reinsurance and Charitable Giving in Insurance

\begin{tabular}{lccc} 
& $(0.00)$ & $(0.00)$ & $(0.00)$ \\
\hline Adjusted & $16 \%$ & $23 \%$ & $497 \%$ \\
pseudo-R & & & 924 \\
No. firms & 924 & 924 & 924 \\
\hline
\end{tabular}

Panel B: Random-effects probit model marginal-effects

\begin{tabular}{|c|c|c|c|c|c|c|}
\hline & \multicolumn{2}{|c|}{ Model 1} & \multicolumn{2}{|c|}{ Model 2} & \multicolumn{2}{|c|}{ Model 3} \\
\hline & $\begin{array}{l}\text { at } \\
\text { means }\end{array}$ & $\begin{array}{l}\text { at } \\
\text { medians }\end{array}$ & $\begin{array}{l}\text { at } \\
\text { means }\end{array}$ & $\begin{array}{l}\text { at } \\
\text { medians }\end{array}$ & $\begin{array}{l}\text { at } \\
\text { means }\end{array}$ & $\begin{array}{l}\text { at } \\
\text { medians }\end{array}$ \\
\hline$R(S I Z E)$ & 2.35 & 2.19 & 1.87 & 0.19 & 1.00 & 0.18 \\
\hline$O W N$ & -0.50 & -0.46 & -0.26 & -0.03 & -0.22 & -0.04 \\
\hline$L E V$ & 0.23 & 0.22 & 0.16 & 0.02 & 0.05 & 0.01 \\
\hline$P-L I N E$ & 5.45 & 5.09 & 5.11 & 0.52 & 6.04 & 0.11 \\
\hline$R(P R O F I T)$ & 0.40 & 0.37 & -0.19 & -0.02 & -0.23 & -0.04 \\
\hline$R(A G E)$ & 0.66 & 0.62 & 2.97 & 0.30 & 1.08 & 0.20 \\
\hline REINS & & & -9.99 & -1.02 & -13.94 & -0.56 \\
\hline OUTS & & & 1.20 & 0.12 & 0.36 & 0.07 \\
\hline SEP & & & 0.46 & 0.05 & -1.64 & -0.30 \\
\hline INSIDE & & & 1.30 & 0.13 & 1.95 & 0.36 \\
\hline COMP & & & -1.12 & -0.11 & -3.37 & -0.62 \\
\hline$G-M I X$ & & & 3.73 & 0.38 & 1.07 & 30.20 \\
\hline $\begin{array}{l}\text { PROF } \\
\text { REINS } x\end{array}$ & & & -0.98 & -0.10 & -0.56 & -0.10 \\
\hline OUTS & & & & & 21.89 & 0.03 \\
\hline $\begin{array}{l}\text { REINS } x \text { SEP } \\
\text { REINS } x\end{array}$ & & & & & 6.36 & 0.17 \\
\hline $\begin{array}{l}\text { INSIDE } \\
\text { REINS } x\end{array}$ & & & & & -2.95 & -0.54 \\
\hline $\begin{array}{l}\text { COMP } \\
\text { REINS } x G-\end{array}$ & & & & & 7.58 & 0.39 \\
\hline$M I X$ & & & & & -34.58 & -0.36 \\
\hline $\begin{array}{l}\text { REINS } x \\
\text { PROF }\end{array}$ & & & & & 4.55 & 0.84 \\
\hline
\end{tabular}

Note: This table gives the results of the random-effects probit model (where the dependent dummy variable is the decision whether or not to donate to charitable causes - DDUM). We replace SIZE, PROFIT and AGE with their rank-transformed equivalents $R(S I Z \mathrm{E}), R(P R O F I T)$ and $R(A G E)$ to address the effects of extreme values. BSIZE is excluded due to multicollinearity. Marginal-effects represent discrete changes from 0 to 1 . Values in parentheses refer to p-values; $* * *$ indicate statistical significance at the $5 \%$, and $1 \%$ levels respectively. Significance levels are one-tail where a one-way direction is predicted, and two-tail, otherwise. 
Table 5: UK Insurers 1999-2010: Estimates and marginal-effects of the tobit model

\begin{tabular}{|c|c|c|c|}
\hline & Model 1 & Model 2 & Model 3 \\
\hline$R(S I Z E)$ & $\begin{array}{c}0.97 * * \\
(0.00)\end{array}$ & $\begin{array}{c}0.47 * * \\
(0.00)\end{array}$ & $\begin{array}{c}0.44 * * \\
(0.00)\end{array}$ \\
\hline$O W N$ & $\begin{array}{c}-0.25^{* *} \\
(0.00)\end{array}$ & $\begin{array}{c}-0.28^{* *} \\
(0.00)\end{array}$ & $\begin{array}{c}-0.24^{* *} \\
(0.00)\end{array}$ \\
\hline$L E V$ & $\begin{array}{c}-0.20 * * \\
(0.00)\end{array}$ & $\begin{array}{c}-0.17 * * \\
(0.00)\end{array}$ & $\begin{array}{c}-0.16^{* *} \\
(0.00)\end{array}$ \\
\hline$P$-LINE & $\begin{array}{c}0.06 \\
(0.08)\end{array}$ & $\begin{array}{c}0.04 \\
(0.44)\end{array}$ & $\begin{array}{c}0.13^{* *} \\
(0.00)\end{array}$ \\
\hline$R($ PROFIT $)$ & $\begin{array}{l}0.11 * * \\
(0.01)\end{array}$ & $\begin{array}{c}0.05 \\
(0.14)\end{array}$ & $\begin{array}{c}0.07^{* *} \\
(0.05)\end{array}$ \\
\hline$R(A G E)$ & $\begin{array}{c}0.16^{* *} \\
(0.00)\end{array}$ & $\begin{array}{c}0.27 * * \\
(0.00)\end{array}$ & $\begin{array}{c}0.41^{* *} \\
(0.00)\end{array}$ \\
\hline REINS & & $\begin{array}{c}-0.57 * * \\
(0.00)\end{array}$ & $\begin{array}{c}-2.33^{* *} \\
(0.00)\end{array}$ \\
\hline OUTS & & $\begin{array}{l}0.20 * * \\
(0.00)\end{array}$ & $\begin{array}{c}0.19^{* *} \\
(0.00)\end{array}$ \\
\hline$S E P$ & & $\begin{array}{l}-0.02 \\
(0.56)\end{array}$ & $\begin{array}{l}-0.11 \\
(0.70)\end{array}$ \\
\hline INSIDE & & $\begin{array}{c}0.19 * * \\
(0.00)\end{array}$ & $\begin{array}{l}0.14^{*} \\
(0.05)\end{array}$ \\
\hline COMP & & $\begin{array}{c}-0.06^{* *} \\
(0.00)\end{array}$ & $\begin{array}{l}-0.16 \\
(0.14)\end{array}$ \\
\hline$G-M I X$ & & $\begin{array}{c}0.60^{* *} \\
(0.00)\end{array}$ & $\begin{array}{c}0.69 * * \\
(0.00)\end{array}$ \\
\hline PROF & & $\begin{array}{c}-0.30 * * \\
(0.00)\end{array}$ & $\begin{array}{c}-0.19^{* *} \\
(0.01)\end{array}$ \\
\hline REINS $x$ OUTS & & & $\begin{array}{c}0.33 \\
(0.97)\end{array}$ \\
\hline REINS $x$ SEP & & & $\begin{array}{c}0.40 \\
(0.67)\end{array}$ \\
\hline REINS x INSIDE & & & $\begin{array}{c}-1.04 * * \\
(0.00)\end{array}$ \\
\hline REINS $x$ COMP & & & $\begin{array}{c}0.32 \\
(0.34)\end{array}$ \\
\hline REINS $x$ G-MIX & & & $\begin{array}{l}-0.79 \\
(0.90)\end{array}$ \\
\hline REINS $x$ PROF & & & $\begin{array}{c}4.17 \\
(0.23)\end{array}$ \\
\hline$\lambda$ & $0.18 * *$ & $0.07 *$ & $0.07^{*}$ \\
\hline & $(0.00)$ & $(0.02)$ & $(0.02)$ \\
\hline Constant & $-1.02 * *$ & $-0.49 * *$ & 0.02 \\
\hline & $(0.00)$ & $(0.01)$ & $(0.95)$ \\
\hline
\end{tabular}




\begin{tabular}{lccc}
\hline Adjusted pseudo- $\mathrm{R}^{2}$ & $52 \%$ & $68 \%$ & $76 \%$ \\
$\mathrm{~N}$ & 427 & 427 & 427 \\
\hline
\end{tabular}

Panel B: tobit model marginal-effects

\begin{tabular}{|c|c|c|c|c|c|c|}
\hline & \multicolumn{2}{|c|}{ Model 1} & \multicolumn{2}{|c|}{ Model 2} & \multicolumn{2}{|c|}{ Model 3} \\
\hline & $\begin{array}{l}\text { at means for } \\
\text { all } \\
\text { observations }\end{array}$ & $\begin{array}{l}\text { at } \\
\text { means } \\
\text { for } \\
\text { don }>0 \\
\end{array}$ & $\begin{array}{l}\text { at means for } \\
\text { all } \\
\text { observations }\end{array}$ & $\begin{array}{l}\text { at means } \\
\text { for } \\
\text { don }>0\end{array}$ & $\begin{array}{l}\text { at means for } \\
\text { all } \\
\text { observations }\end{array}$ & $\begin{array}{l}\text { at means } \\
\text { for } \\
\text { don }>0\end{array}$ \\
\hline$R(S I Z E)$ & 0.06 & 0.28 & 0.14 & 0.10 & 0.10 & 01.0 \\
\hline$O W N$ & 0.01 & -0.07 & -0.08 & -0.10 & -0.06 & -0.06 \\
\hline$L E V$ & 0.02 & 0.06 & 0.05 & 0.00 & 0.04 & 0.04 \\
\hline$P-L I N E$ & 0.02 & 0.02 & 0.01 & 0.00 & 0.01 & 0.02 \\
\hline$R(P R O F I T)$ & 0.01 & 0.03 & 0.01 & 0.00 & 0.09 & 0.09 \\
\hline$R(A G E)$ & 0.02 & 0.05 & 0.08 & 0.10 & -0.53 & -0.548 \\
\hline REINS & & & -0.17 & -0.10 & -0.04 & -0.04 \\
\hline OUTS & & & 0.06 & 0.10 & -0.03 & -0.03 \\
\hline SEP & & & -0.01 & 0.00 & -0.03 & -0.03 \\
\hline INSIDE & & & 0.07 & 0.10 & -0.05 & -0.05 \\
\hline COMP & & & -0.02 & 0.00 & 0.16 & 0.16 \\
\hline$G-M I X$ & & & 0.18 & 0.20 & -0.04 & -0.04 \\
\hline PROF & & & -0.09 & -0.10 & -0.03 & -0.03 \\
\hline REINS $x$ OUTS & & & & & 0.09 & 0.09 \\
\hline REINS $x$ SEP & & & & & 0.24 & 0.24 \\
\hline REINS x INSIDE & & & & & 0.07 & 0.07 \\
\hline REINS $x$ COMP & & & & & 0.18 & 0.18 \\
\hline REINS $x$ G-MIX & & & & & 0.95 & 0.97 \\
\hline REINS $x$ PROF & & & & & 0.10 & 0.10 \\
\hline
\end{tabular}

Note: This table gives the results of the tobit model (where the dependent bivariate (dummy) variable is the financial amount donated to donate to charitable causes - DON). BSIZE is excluded due to multicollinearity. Marginal-effects represent discrete changes from 0 to 1 . We replace SIZE, PROFIT and $A G E$ with their ranktransformed equivalents $R(S I Z E), R(P R O F I T)$ and $R(A G E)$ to address the effects of extreme values. In panel A, $\lambda$ is the inverse mills ratio. Values in parentheses refer to p-values; $* * *$ indicate statistical significance at $5 \%$, and $1 \%$ levels respectively. Significance levels are one-tail where a one-way direction is predicted, and two-tail, otherwise. 